\title{
Modulation of RNA splicing associated with Wnt signaling pathway using FD-895 and pladienolide B
}

\author{
Deepak Kumar ${ }^{1,2,{ }^{*}}$, Manoj K. Kashyap ${ }^{1,3,{ }^{*}}$, Zhe $\mathbf{Y u}^{1}$, Ide Spaanderman ${ }^{1}$, Reymundo Villa ${ }^{4}$, \\ Thomas J. Kipps ${ }^{1,5}$, James J. La Clair ${ }^{4}$, Michael D. Burkart ${ }^{4}$, Januario E. Castro ${ }^{1,5,6}$ \\ ${ }^{1}$ Moores Cancer Center, University of California San Diego, La Jolla, CA 92093, USA \\ ${ }^{2}$ ThermoFisher Scientific, Carlsbad, CA 92008, USA \\ ${ }^{3}$ Amity Stem Cell Institute, Amity Medical School, Amity University Haryana, Panchgaon (Manesar), Haryana \\ 122413, India \\ ${ }^{4}$ Department of Chemistry and Biochemistry, University of California San Diego, La Jolla, CA 92093, USA \\ ${ }^{5}$ CLL Research Consortium and Department of Medicine, University of California San Diego, La Jolla, CA 92093, \\ USA \\ ${ }^{6}$ Hematology-Oncology Division, Mayo Clinic, Phoenix, AZ 85054, USA \\ *Equal contribution
}

Correspondence to: Manoj K. Kashyap, Januario E. Castro, Michael D. Burkart; email: $\underline{\text { mkkashyap@ggn.amity.edu, }}$ castro.januario@mayo.edu, mburkart@ucsd.edu

Keywords: splice modulation, pladienolide B, FD-895, splicing, spliceosome, intron retention, Wnt signaling

Received: December 28, $2021 \quad$ Accepted: February 22, $2022 \quad$ Published: March 1, 2022

Copyright: (C) 2022 Kumar et al. This is an open access article distributed under the terms of the Creative Commons Attribution License (CC BY 3.0), which permits unrestricted use, distribution, and reproduction in any medium, provided the original author and source are credited.

\begin{abstract}
Alterations in RNA splicing are associated with different malignancies, including leukemia, lymphoma, and solid tumors. The RNA splicing modulators such as FD-895 and pladienolide B have been investigated in different malignancies to target/modulate spliceosome for therapeutic purpose. Different cell lines were screened using an RNA splicing modulator to test in vitro cytotoxicity and the ability to modulate RNA splicing capability via induction of intron retention (using RT-PCR and qPCR). The Cignal Finder Reporter Array evaluated [pathways affected by the splice modulators in HeLa cells. Further, the candidates associated with the pathways were validated at protein level using western blot assay, and gene-gene interaction studies were carried out using GeneMANIA. We show that FD-895 and pladienolide B induces higher apoptosis levels than conventional chemotherapy in different solid tumors. In addition, both agents modulate Wnt signaling pathways and mRNA splicing. Specifically, FD-895 and pladienolide B significantly downregulates Wnt signaling pathway-associated transcripts (GSK3 $\beta$ and LRP5) and both transcript and proteins including LEF1, CCND1, LRP6, and pLRP6 at the transcript, total protein, and protein phosphorylation's levels. These results indicate FD-895 and pladienolide B inhibit Wnt signaling by decreasing LRP6 phosphorylation and modulating mRNA splicing through induction of intron retention in solid tumors.
\end{abstract}

\section{INTRODUCTION}

RNA splicing and the protein machinery that guides this process, the spliceosome, constitute a very relevant biological target for cancer therapy [1, 2]. Others and we have discovered small molecule leads that modulate the spliceosome and induce apoptosis preferentially in cancer cells $[1,3]$. The spliceosome macromolecules are divided into two groups: the major spliceosome, which includes U1, U2, U4, U5, U6 snRNAs, and the minor spliceosome, which comprises U11, U12 together with U5 [4, 5]. Within 
the major component, the SF3B core unit is comprised of spliceosome associated proteins including SF3B1 (Splicing Factor 3b Subunit 1), U2AF1 (U2 Small Nuclear RNA Auxiliary Factor 1), and SRSF2 (Serine And Arginine Rich Splicing Factor 2) that have been implicated in large a number of malignancies [6] including chronic lymphocytic leukemia (CLL) [7], uveal melanoma [8], and myelodysplastic syndrome [9]. Recent structural studies have shown that pladienolide B-related FD-895 polyketides and their analogs bind to a specific pocket within this SF3B core comprised of SF3B1, SF3B3 (Splicing factor 3B subunit 3), and PHF5A (PHD Finger Protein 5A) [10, 11]. SF3B1 and mutations in it have been exploited extensively as a therapeutic target in FLT3/ITD positive acute myeloid leukemia (AML), endometrial cancer, and hepatocellular carcinoma [12-14].

To date, a panel of splicing modulators (SPLMs) have been screened using in vitro and in vivo models for their ability to inhibit the spliceosome, and their anti-cancer properties [6]. Those compounds include FR901464 $[15,16]$, spliceostatin A (a derivative of FR901464) [17], thailanstatin A [18], meayamycin [19], isoginkgetin [20], sudemycin (analogs of FR901464) $[21,22]$, and herboxidiene [23]. The activity of SPLMs, including spliceostatin A [24], and sudemycin analogs (sudemycin $\mathrm{C} 1$, sudemycin D6), includes prominent induction of intron retention (IR) and exon skipping (ES) which are types of alternative RNA splicing events observed in different cell lines [25-27]. While many of these agents showed splice modulatory activity, but their primary mechanisms of inducing tumor cell death remain unknown.

E7107 (a synthetic analog of pladienolide B) entered Phase 1 clinical trials by groups at MD Anderson in Houston [28], and the Erasmus University Medical Center in Rotterdam [29]. A total of 26 patients with solid tumors were enrolled in the US-based Phase I and treated at escalating doses beginning at $0.6 \mathrm{mg} / \mathrm{m}^{2}$. E7107 was received as a 30-minute intravenous infusion on days 1 and 8 and repeated this cycle every 21 days. The selection of subsequent dose levels was performed according to accelerated design. The maximum tolerable dose (MTD) for E7107 observed was $4.3-\mathrm{mg} / \mathrm{m}^{2}$. A total of $31 \%$ of patients showed stable disease. The adverse events associated with E7107 were diarrhea, vomiting, and nausea. Blindness was observed in two patients at the 2 nd and 7 th cycle after receiving $3.2 \mathrm{mg} / \mathrm{m}^{2}$ and $4.3 \mathrm{mg} / \mathrm{m}^{2}$, respectively. The loss of vision event in patients led to the discontinuation of this study [28].

In the Dutch Phase, I trial, 40 patients with solid tumors were enrolled, and doses from 0.6 to $4.5 \mathrm{mg} / \mathrm{m}^{2}$ were explored. The MTD was $4.0 \mathrm{mg} / \mathrm{m}^{2}$. At 4.5 $\mathrm{mg} / \mathrm{m}^{2}$, two patients experienced diarrhea of grade 4 . At $4.0-4.5 \mathrm{mg} / \mathrm{m}^{2}$, dose-limiting toxicity (DLT) grade 3 diarrhea, nausea, vomiting, and abdominal cramps were observed. After drug discontinuation at $4.0 \mathrm{mg} / \mathrm{m}^{2}$, one patient experienced reversible grade 4-blurred vision. The pharmacokinetic analysis revealed a plasma halflife between 5.3 to $15.1 \mathrm{~h}$. There were no complete or a partial response was observed in this trial. Severe issues with vision were observed in both trials. An increase in the pre-mRNA (intron retained) was observed in this study at MTD in the peripheral blood mononuclear cells [29]. Both trials were ultimately suspended.

In our previous studies, we explored the activity of SPLMs on normal peripheral blood mononuclear cells (PBMCs) including $\mathrm{T}$ and B-lymphocytes and found that SPLMs spare these cells as compared with leukemic B cells. We also reported that FD-895 and pladienolide B exhibited modulation of mRNA spicing and induced apoptosis in patient-derived CLLB cells [30]. Here we found that FD-895 and related synthetic analogs block the G2/M phase of the cell cycle, downregulating the cyclin D1 (CCND1), phospho-CDC2, CDC2, and modulating PLK-1 splicing [31].

The activity of FD-895 and pladienolide B has not been evaluated in solid tumor cells lines to assess the effect of induction of intron retention on Wnt signaling pathway, therefore we designed studies to evaluate their apoptotic activity against solid tumors and the mechanisms involved in this process.

\section{MATERIALS AND METHODS}

\section{Ethical statement}

Informed consent was taken of the healthy donor prior to collection of blood samples from San Diego Blood Bank according to the regulation of the Institutional Review Board and Ethics committee at UC San Diego and maintained strict compliance with the Helsinki Declaration.

\section{Compounds}

FD-895 was prepared through total synthesis [32]. Pladienolide B (sc-391691, Santa Cruz Biotechnology, Santa Cruz, CA, USA), etoposide (E1383, Sigma-Aldrich, St Louis, MO, USA) and cisplatin (479306, Sigma-Aldrich, St Louis, MO, USA) were obtained commercially (Figure 1). Oligonucleotides were purchased via custom synthesis (Integrated DNA Technologies). 


\section{Cell culture methods}

The MCF-7 (RRID:CVCL_0031), MDA-MB-468 (RRID:CVCL 0419), HS578T (breast cancer, RRID:CVCL_0332), A2780 (RRID:CVCL_0134), SKOV3 (ovarian cancer, RRID:CVCL_0532), 786-O (renal adenocarcinoma, RRID:CVCL_1051), HeLa (Cervical cancer, RRID:CVCL_0030), and HEK-293 cell lines were obtained from ATCC. MCF7 was cultured in DMEM (catalog \# 12800017, GIBCO, Grand Island, USA) $+10 \%$ fetal bovine serum (FBS, catalog \# FB-02, Omega Scientific, Tarzana, CA, USA) $+2 \mathrm{mM} \mathrm{L}$-glutamine and $1 \% \mathrm{Pen} / \mathrm{Strep}$ (catalog \# 15140148, Invitrogen Corporation, CA, USA) supplemented with $0.01 \mathrm{mg} / \mathrm{mL}$ human recombinant insulin. Other cell lines were maintained in DMEM supplemented with $10 \%$ FBS, $2 \mathrm{mM} \mathrm{L}$-glutamine, and $1 \%$ of Pen/Strep. Additionally, two ovarian cancer cell lines with differential cisplatin sensitivity, OV-2008 (sensitive, RRID:CVCL_0473) and it's resistant variant C13 were obtained from Prof. Stephen Howell (UC San Diego). To complete the set, a final colon cancer cell line HCT116 (RRID:CVCL_0291) was obtained from the Johns Hopkins School of Medicine, Baltimore, MD. The suspension cell lines including Jeko-1, JVM2, and Mino cell lines were cultured in RPMI-1640 (catalog \# R7509, Sigma) supplemented with $10 \%$ FBS along with $1 \%$ Pen-Strep. All cell lines were incubated at $37^{\circ} \mathrm{C}$ in an atmosphere of $5 \% \mathrm{CO}_{2}$ and routinely monitored for Mycoplasma infections by PCR analyses.

\section{Flow cytometry analyses}

Normal PBMCs were treated with FD-895 (100 nM to $2.0 \mu \mathrm{M})$, and pladienolide $\mathrm{B}(100 \mathrm{nM}$ to $2.0 \mu \mathrm{M})$, for $48 \mathrm{~h}$. Cell viability was determined by flow cytometry after staining with conventional live staining with $40 \mu \mathrm{M} 3,3$ 'dihexyloxacarbocyanine iodide $\left(\mathrm{DiOC}_{6}\right.$; Life Technologies, Carlsbad, CA, USA) and $15 \mu \mathrm{M}$ $(10 \mu \mathrm{g} / \mathrm{mL})$ of propidium iodide (PI; Sigma-Aldrich, St Louis, MO, USA). Data were analyzed by using FlowJo software (version 6.4.7; Tree Star). Using this assay, viable cells excluded PI and stained brightly positive for $\mathrm{DiOC}_{6}$ as it targets metabolically active mitochondria of alive cells [30-33].

\section{Calculation of \% specific induced apoptosis (SIA)}

To discriminate the compound specific induced apoptosis vs. background spontaneous cell death from in vitro culture conditions, we calculated the percentage of specific induced apoptosis (\% SIA) using the following formula: $\%$ SIA $=[$ (compound induced apoptosis - media only spontaneous apoptosis $) /(100-$ media only spontaneous apoptosis) $] \times 100$.

\section{Cell proliferation assays}

The cell proliferation assays were conducted in adherent cell lines (HCT116, MCF-7, MDA-MB-468, HS578T, OV-2008, A2780, SKOV3, 786-O, HEK-293, and $\mathrm{HeLa}$ ) by using CellTiter 96 AQueous non-radioactive colorimetric method (G5421, Promega, Madison, WI, USA). Briefly, a total of 3000 cells/well were seeded in a 96-well flat-well plate followed by treatment with FD$895(100 \mathrm{nM}$ to $2.0 \mu \mathrm{M})$, pladienolide B (100 nM to 2.0 $\mu \mathrm{M})$, cisplatin $(1 \mu \mathrm{M}$ to $30 \mu \mathrm{M})$ or etoposide $(1 \mu \mathrm{M}$ to $30 \mu \mathrm{M}$ ) in triplicate for $48 \mathrm{~h}$ at $37^{\circ} \mathrm{C}$. Following the incubation, $20 \mu \mathrm{L}$ of CellTiter 96 AQueous solution (Promega, Madison, WI, USA) was added directly to each well. Non-treated cells were considered as the control. After staining, the plates were incubated for an additional $2 \mathrm{~h}$ and then read on a 96-well plate reader (Molecular Devices, Sunnyvale, CA, USA). Absorbance readings were recorded absorbance at 490 nm using empty wells (air) for background collection.

\section{Reverse transcriptase PCR (RT-PCR) analyses}

HCT116, MCF-7, MDA-MB-468, HeLa, Jeko-1, JVM2 and Mino cells $\left(10^{6}\right.$ cells/well) were treated with 100 nM FD-895, $100 \mathrm{nM}$ pladienolide $\mathrm{B}, 30 \mu \mathrm{M}$ cisplatin or $30 \mu \mathrm{M}$ etoposide for $4 \mathrm{~h}$. RNA isolation was done using mirVana miRNA Isolation Kit (Ambion, Austin, Texas). The $200 \mathrm{ng}$ of RNA was subjected to DNase I (Life Technologies, Carlsbad, CA, USA). The cDNA was prepared by using SuperScript III Reverse Transcriptase Kit (Life Technologies, Carlsbad, CA, USA), and PCR reactions were performed in $20 \mu \mathrm{L}$ of reaction volume. PCR conditions were $95^{\circ} \mathrm{C}$ for $3 \mathrm{~min}$; 35 cycles of $95^{\circ} \mathrm{C}$ for $30 \mathrm{~s}, 58^{\circ} \mathrm{C}$ for $30 \mathrm{~s}$, and $72^{\circ} \mathrm{C}$ for $45 \mathrm{~s}$; followed by $72^{\circ} \mathrm{C}$ for $5 \mathrm{~min}$. PCR products were separated on a $2 \%$ agarose gel and stained with ethidium bromide. Details of the primers used for RTPCR are described in Table 1.

\section{Quantitative reverse transcriptase-PCR (qRT-PCR) analyses}

The HeLa cells were treated with $100 \mathrm{nM}$ FD-895 or $100 \mathrm{nM}$ pladienolide B for $6 \mathrm{~h}, 12 \mathrm{~h}$, or $24 \mathrm{~h}$, and the RNA isolation and cDNA preparation were done as described above. The amounts of mRNA of LEF1 (Lymphoid enhancer-binding factor-1), FN1 (fibronectin 1), and CCND1 genes were determined using Power SYBR Green PCR master mix (Applied Biosystems, Foster City, CA) real-time qRT-PCR using specific primers [34]. PCR was conducted using 5 picomoles of each primer and $20 \mathrm{ng}$ of the obtained cDNA. PCR conditions were $50^{\circ} \mathrm{C}$ for $2 \mathrm{~min} ; 95^{\circ} \mathrm{C}$ for $10 \mathrm{~min}$; 40 cycles of $94^{\circ} \mathrm{C}$ for $15 \mathrm{~s}$, and $60^{\circ} \mathrm{C}$ for $1 \mathrm{~min}$. The mRNA levels were calculated using the $2^{-\Delta \Delta C T}$ 
Table 1. Sequences of primers used in the RT-PCR.

\begin{tabular}{|c|c|}
\hline Primer & Sequence \\
\hline DNAJBI-FW & 5'-GAACCAAAATCACTTTCCCCAAGGAAGG-3' \\
\hline DNAJB1-RV & 5'-AATGAGGTCCCCACGTTTCTCGGGTGT-3' \\
\hline$R N U 6 A-\mathrm{FW}$ & 5'-CGCTTCGGCAGCACATATAC-3' \\
\hline$R N U 6 A-\mathrm{RV}$ & 5'-GAATTTGCGTGTCATCCTT-3' \\
\hline$L E F 1-F P$ & 5'-AGGAACATCCCCACACTGAC-3'; \\
\hline$L E F 1-R P$ & 5'-AGGTCTTTTTGGCTCCTGCT-3' \\
\hline$C C N D 1-F P$ & 5'-AATGACCCCGCACGATTTC-3' \\
\hline$C C N D 1-R P$ & 5'-TCAGGTTCAGGCCTTGCAC-3' \\
\hline FN1-FP & 5'-ACCTACGGATGACTCGTGCTTT-3' \\
\hline FN1-RP & 5'-TTCAGACATTCGTTCCCACTCA-3' \\
\hline GSK3ß-FP & 5'-ATCAAGGCACATCCTTGGAC-3' \\
\hline GSK3ß-RP & 5'-CAATTGCCTCTGGTGGAGTT-3' \\
\hline LRP5-FP & 5'-GCCTGCAACAAGTGGACA-3' \\
\hline LRP5-RP & 5'-CCTGCAGCACTATGTCTGTGA-3' \\
\hline
\end{tabular}

FP and RP denote forward and reverse primers respectively.

method [35]. GAPDH was used as a control for normalization.

\section{Pathway reporter arrays}

Cignal Finder Reporter Array (336821, Qiagen/ SABiosciences, Frederick, MD, USA) was used to assess 45 different signaling pathways. HeLa cells were seeded into wells (50,000 cells/well) of the Cignal Finder 96-well plates (CCA-901L, Qiagen, SABiosciences, Frederick, MD, USA) for introducing pathway reporters into cells by reverse transfection according to the manufacturer's protocol. Briefly, reporter DNA constructs in each plate well were re-suspended with $50 \mu \mathrm{L}$ Opti-MEM and then mixed with $50 \mu \mathrm{L}$ diluted Lipofectamine 2000 transfection (Life Technologies, Carlsbad, CA, USA) reagent. Cells were suspended in Opti-MEM (Life Technologies, Carlsbad, CA, USA) supplemented with $10 \%$ of FBS and $0.1 \mathrm{mM}$ non-essential amino acids at a density of $6 \times 10^{5}$ cells $/ \mathrm{mL}$, and then $50 \mu \mathrm{L}$ of the cell suspension was added into each plate well and mixed with DNA resident in the plate and added transfection reagent. The cells were incubated for $3 \mathrm{~h}$. Following transfection; the cells were treated with vehicle (Opti-MEM) or 100 nM FD-895 for 3 $\mathrm{h}$ in Opti-MEM media. Luciferase and renilla expression were determined (Qiagen/SABiosciences Corp., Frederick, MD, USA).

\section{Western blot analyses}

HeLa cells were treated with $100 \mathrm{nM}$ FD-895 or $100 \mathrm{nM}$ pladienolide B for $12 \mathrm{~h}, 24 \mathrm{~h}$, and $48 \mathrm{~h}$ for $\beta$-catenin, LEF1, LRP6 (LDL Receptor Related Protein 6), and phospho-LRP6. The cells were then washed with PBS $(2 \times 5 \mathrm{~mL})$ and lysed with modified RIPA buffer at $4^{\circ} \mathrm{C}$. Untreated cells were used as a control. The wholecell protein was quantified according to the Bradford method [36]. Lysates in sample buffer (2\% Sodium dodecyl sulfate (SDS), $10 \%$ glycerol, $80 \mathrm{mM}$ Tris $\bullet \mathrm{HCl}$ (pH 6.8), $720 \mathrm{mM} \quad \beta$-mercaptoethanol and $0.001 \%$ bromophenol blue) were denatured at $95^{\circ} \mathrm{C}$ for $5 \mathrm{~min}$. Total cellular proteins ( $30 \mu \mathrm{g}$ via Bradford analyses) were subjected to SDS-polyacrylamide gel electrophoresis (PAGE) using a 4-20\% Criterion Precast Gel (Bio-Rad, Hercules, CA), and the proteins were transferred to polyvinylidene difluoride (PVDF) membrane (Millipore, Bedford, MA). After blocking with $5 \%$ bovine serum albumin (BSA) for $1 \mathrm{~h}$ in Trisbuffered saline, $0.1 \%$ Tween 20 (TBST, $20 \mathrm{mM}$ Tris $\bullet \mathrm{HCl}, 137 \mathrm{mM} \mathrm{NaCl}, 0.1 \%$ Tween-20 pH 7.6), the membrane was incubated with the following primary antibody overnight at $4^{\circ} \mathrm{C}$. The primary antibodies include rabbit $\mathrm{mAb}$ anti-LEF1, rabbit anti-PhosphoLRP6 (Ser1490), rabbit anti-LRP6, rabbit mAb anti- $\beta$ catenin, and mouse $A b$ anti- $\beta$-actin were obtained from Cell Signaling Technology (Beverly, MA) and used at a dilution of 1:1000. After primary $\mathrm{mAb}$ staining and washing thrice with TBST, the membranes were incubated with HRP-labeled anti-rabbit (sc-2030, Santa Cruz Biotechnology) or HRP-labeled anti-mouse (sc2031, Santa Cruz Biotechnology) secondary antibodies with a dilution of 1:5000 dilutions for $40 \mathrm{~min}$ at rt. After incubation, the membrane was washed thrice with TBST and developed using an enhanced 
Table 2. IC 50 values for FD-895 and pladienolide B in selected tumor cell lines.

\begin{tabular}{lccc}
\hline Cell lines & Type of Cancer & FD-895 (nM) & Pladienolide B (nM) \\
\hline HCT116 (TP53, +/+) & Colon & $34.1 \pm 2.4$ & $42.3 \pm 3.1$ \\
HCT116 (TP53, +/-) & Colon & $75.2 \pm 2.5$ & $65.6 \pm 2.9$ \\
HCT116 (TP53,-/-) & Colon & $100.7 \pm 1.2$ & $88.6 \pm 2.0$ \\
MCF-7 (TP53, +/+) & Breast & $51.7 \pm 1.9$ & $38.7 \pm 3.8$ \\
MDA-MB-468 (TP53,+/-) & Breast & $30.7 \pm 2.1$ & $38.5 \pm 3.8$ \\
HS578T (TP53,-/-) & Breast & $139.7 \pm 1.1$ & $112.0 \pm 3.1$ \\
OV-2008 & Ovarian & $311.6 \pm 2.2$ & $344.5 \pm 1.3$ \\
A2780 & Ovarian & $415.0 \pm 5.2$ & $337.0 \pm 7.0$ \\
SKOV3 & Ovarian & $143.4 \pm 2.1$ & $128.7 \pm 3.2$ \\
786-O & Renal & $412.5 \pm 2.4$ & $293.6 \pm 3.1$ \\
HeLa & Cervical & $131.0 \pm 3.3$ & $118.4 \pm 4.4$ \\
\hline
\end{tabular}

chemiluminescence (ECL) kit (Pierce Thermo Scientific Inc., Rockford, IL).

\section{Bioinformatics analysis}

Gene-gene interaction networks were predicted and generated with GeneMANIA (Gene Multiple Association Network Integration Algorithm) available at http://genemania.org [37].

\section{Statistical analysis}

The data presented as mean \pm standard deviation (SD). The data was analyzed using GraphPad Prism 6.0 (GraphPad Software, La Jolla, CA). Multiple groups were compared using Bonferroni correction and $p<$ 0.05 was considered statistically significant.

\section{Ethics approval and consent to participate}

The study involved human, animal or cell lines as a material for experimental purpose and the ethical clearance was conducted before starting the study.

\section{Consent for publication}

All authors consent to the publication of the manuscript in "Aging". Further, figures or tables are original, so there was no requirement of taking permission or consent from anyone.

\section{Availability of data and material}

All data generated and analyzed during our study are included in the published article.

\section{RESULTS}

In vitro cytotoxicity evaluation of FD-895 and pladienolide B in colon, breast, cervical cancer cell lines

We previously reported the apoptotic activity of FD-895 and pladienolide B in CLL-B, mantle cell lymphoma (MCL), and other B and T lymphoma cell lines [31] Further, we were interested in exploring the apoptotic activity of FD-895 and pladienolide B in different solid tumor cell lines (Figure 1A-1D). The chemical structure of both SPLMs has been shown in Figure 1F. Using an expanded panel of cell lines, we found that FD-895 and pladienolide $\mathrm{B} \mathrm{IC}_{50}$ ranged from $30.7 \pm 2.2$ to $415.0 \pm$ $5.3 \mathrm{nM}$ (Table 2) across the breast, colon, and cervix tumor cell lines (Figure 1A-1D). Upon treatment of normal PBMCs with FD-895 and pladienolide B, the lack of activity $\left(\mathrm{IC}_{50}\right.$ values $\leq 450 \mathrm{nM}$ ) was not achieved in normal PBMCs, an observation that suggests that both the FD-895 and pladienolide B spare the normal PBMCs, but not the leukemic B cells (Figure 1E) [30]. We also tested the normal cell line HEK-293 in response to FD-895 (100 nM to $2 \mu \mathrm{M})$ and found that there was non-significant cell death induced with varying concentrations of FD-895 when compared with control $(p>0.05)$, but cisplatin $(30 \mu \mathrm{M})$ induced significant cell death in HEK-293 cells $(p<0.05$, Supplementary Figure 1).

Cytotoxic evaluation of FD-895 and pladienolide B in ovarian cancer cells regardless of differential cisplatin sensitivity

Next, we turned our attention to explore the activity of splice modulation on cell lines displaying sensitivity or 
resistance to cisplatin, as the latter is an issue in the treatment of solid tumors including ovarian [38], cervical cancer [39], gastric adenocarcinoma [40], prostate cancer [41], colorectal [42], and head and neck squamous cell carcinoma [43]. Here, we used two human ovarian cancer cell lines, one consisting of a cisplatin-sensitive parental line, OV2008, and the other stably cisplatin-resistant subline, OV2008/C13 derived by in vitro selection with cisplatin. We began by screening these cell lines for their induction of apoptosis when treated with FD-895, pladienolide B, cisplatin, or etoposide. FD-895 and pladienolide B induced significant apoptosis in both parental and cisplatinresistant OV2008 cells (Figure 2A, 2B). We also observed that FD-895 and pladienolide B demonstrated significant apoptosis in A2780 and SKOV3 ovarian cancer cell lines as compared to cisplatin and etoposide (Figure 2C, 2D). These findings suggest that nanomolar concentrations of SPLMs have the potential to overcome cisplatin resistance. We also evaluated the apoptotic activity of FD-895 and pladienolide B in 786$\mathrm{O}$ (renal) cancer cells. We found that both splice modulators were ten-fold more efficient at induced apoptosis than cisplatin and etoposide (Figure 2E).

\section{FD-895 and pladienolide $B$ induced spliceosome modulation marked by intron retention in cancer cells}

In previous studies, we found that FD-895 and pladienolide B induced IR in CLL and MCL cells [3032]. Here, we expand our understanding of their ability to induce IR across an expanded panel of cancer cell lines, including Jeko-1, Mino, JVM2, HeLa, HCT116, MCF-7, and MDA-MB-468 cell lines. In brief, we incubated $10^{6}$ cells/well from each cell line with a 100 nM FD-895, $100 \mathrm{nM}$ pladienolide $\mathrm{B}, 30 \mu \mathrm{M}$ cisplatin or
A

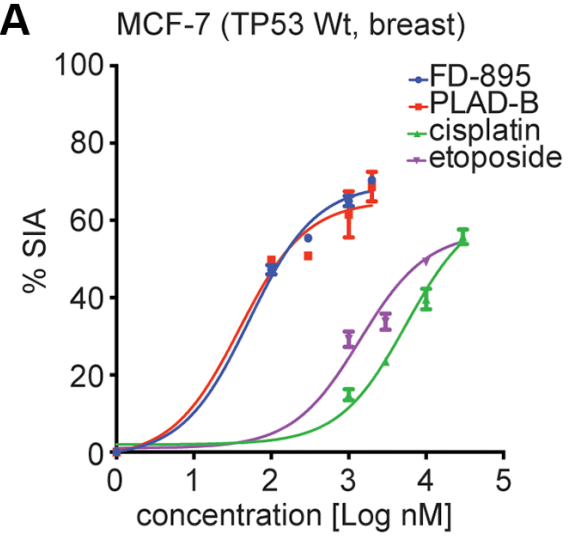

D

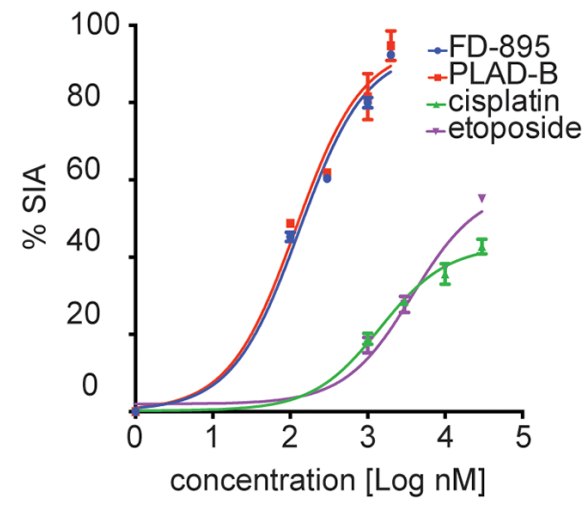

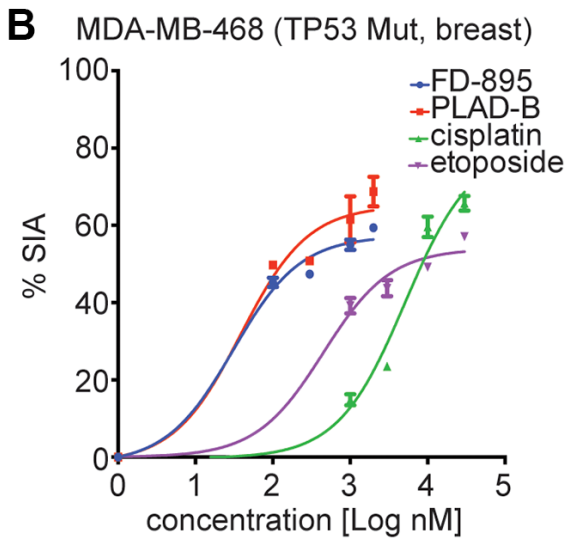

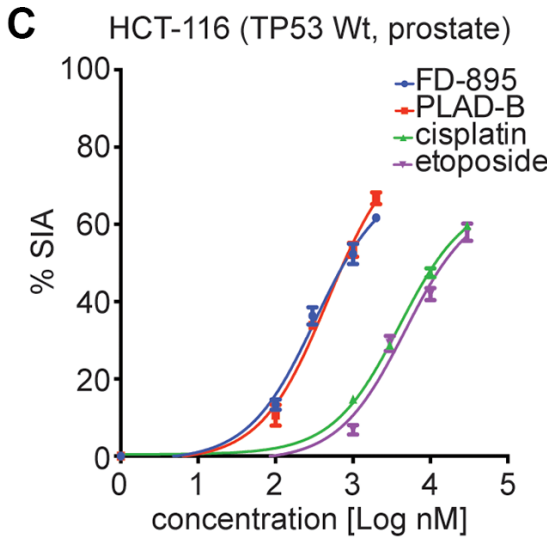

E

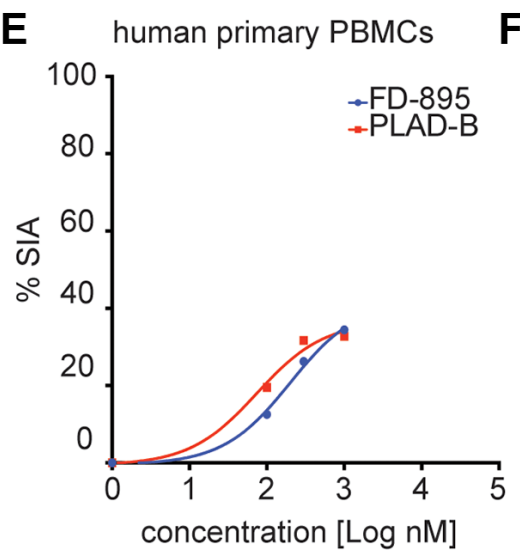

Figure 1. In vitro cytotoxicity induced by FD-895 and pladienolide B in different cancer cell lines, and normal human primary PBMCs. Cancer Cells were exposed to FD-895 (100 nM to $2 \mu \mathrm{M})$, pladienolide B (100 nM to $2 \mu \mathrm{M}$ ), etoposide $(1 \mu \mathrm{M}$ to $30 \mu \mathrm{M})$, and cisplatin $(1 \mu \mathrm{M}$ to $30 \mu \mathrm{M})$ for $48 \mathrm{~h}$. Apoptosis were measured in MCF-7 (A), MDA-MB-468 (B), HCT-116 (C) and HeLa (D) cells using MTS assay. The absorbance of the control (cells without treatment) was subtracted from the treated cells of each cell line. (E) Normal PBMC cells were exposed to FD-895, and pladienolide B. Cells were stained with propidium iodide and DiOC $_{6}$ to differentiate dead and viable cells by using flow cytometer. Data presented in form of \% specific induced apoptosis (\% SIA). To assess the compound specific induced apoptosis vs. background spontaneous cell death from in vitro culture conditions, we calculated the percentage of SIA using the following formula: \% $\mathrm{SIA}=[($ compound induced apoptosis - media only spontaneous apoptosis $) /(100-$ media only spontaneous apoptosis $)] \times 100$. The data shows the results of samples analyzed in duplicate with the mean and its respective SD. (F) Structures of pladienolide-B and FD-895. 
$30 \mu \mathrm{M}$ etoposide for $4 \mathrm{~h}$. After treatment, the levels of spliced and unspliced gene expression were evaluated by RT-PCR. We observed that cells treated with FD895 or pladienolide B demonstrated IR, which was not observed with non-splice modulatory controls, cisplatin, or etoposide (Figure 3) using DNAJB1 (DnaJ Heat Shock Protein Family (Hsp40) Member B1) as a surrogate marker for spliceosome modulation [30]. IR was observed in cells treated with FD-895 or pladienolide B for DNAJB1 when compared to the intronless gene $R N U 6 A$ used as a loading control RNA (Figure $3 \mathrm{~A}-3 \mathrm{G}$ ).

\section{FD-895 downregulates and modulates splicing of proteins involved in Wnt signaling}

To investigate the intracellular signaling pathways affected by FD-895, we applied the Cignal 45-Pathway Reporter Array to simultaneously analyze FD-895 effect on 45 different signaling pathways [44]. HeLa cells, selected due to their SPLM sensitivity, were treated with FD-895 over $12 \mathrm{~h}$ and baseline-signaling profile was compared to vehicle control (Figure 4A). Interestingly, treatment with $100 \mathrm{nM}$ FD-895 modulated a number of pathways including notch signaling, octamer-binding transcription factor 4 (OCT4), activating transcription factor 6 (ATF6), NANOG, and Wnt signaling pathway as early as within $1 \mathrm{~h}$ but decreased as the time progressed (Figure 4A).

Among these pathways, we found that the Wnt signaling pathway was activated at an early time point but downregulated as the duration of FD-895 prolonged, as monitored by the TCF/LEF reporter in cervical cancer cell line HeLa (Figure 4A).

Alternative RNA splicing events have been reported within the Wnt signaling pathway for various molecules such as in LRP6, ROR, Axin, APC, CK1, and Catenin, beta-1 (CTNNB1) [45]. We selected Wnt signaling pathway not only because of this but also because Wnt5A overexpression has been reported in multiple cancers and it is associated with disease progression, metastasis, and resistance to treatment [46]. Additionally, there were several reasons to select LRP5 and GSK-3 $\beta$ for further validation. We know that both lipoprotein receptor-related protein (LRP) 5 and 6 are crucial Wnt co-receptors and interact with other
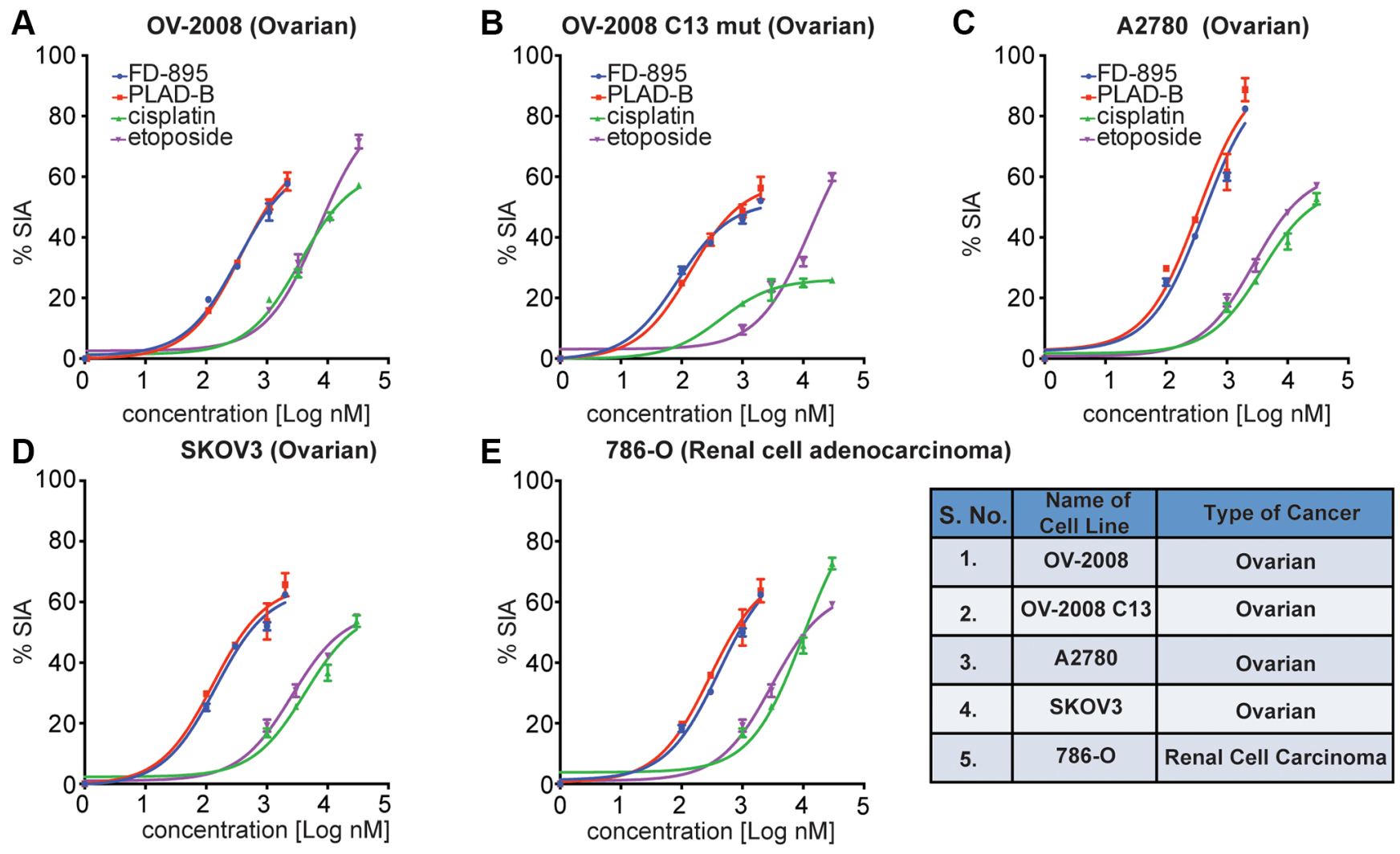

Figure 2. FD-895 or by pladienolide B induced apoptosis in ovarian and renal cancer cells. Ovarian cancer cells (A) OV-2008, cisplatin sensitive (B) OV-2008 C13 mut, cisplatin resistant, (C) A2780, (D) SKOV3 or (E) renal cancer cells (786-O) were incubated with FD$895(100 \mathrm{nM}$ to $2 \mu \mathrm{M})$, pladienolide B (100 nM to $2 \mu \mathrm{M})$, etoposide $(1 \mu \mathrm{M}$ to $30 \mu \mathrm{M})$, or of cisplatin $(1 \mu \mathrm{M}$ to $30 \mu \mathrm{M})$ for $48 \mathrm{~h}$. Cells viability were measured as using MTS assay. This experiment was repeated in triplicate independently. Data presented in form of \% SIA. The data shows the results of samples analyzed in duplicate with the mean and its respective SD. 
components of the Wnt signaling pathway. Additionally, both LRP5 and LRP6 are oncogenic proteins as well. Similarly, GSK-3 $\beta$, a serine-threonine kinase and a negative regulator of the oncogenic Wnt/ $\beta$-catenin signaling pathway [47]. Moreover, the role of Wnt signaling has been well established in CLL [34], and in our previous study, in the RNAseq data analysis, we found that both LRP5 and GSK-3 $\beta$ were found to have 3.44, and 5.1-fold IR, respectively in CLL-B cells treated with splice modulator compared with control CLL [30].

From this data, we selected Wnt signaling pathway to study further because as Wnt5A overexpressed and has been correlated with cervical carcinoma [46]. We began by exploring its effect on the TCF/LEF reporter system. As shown in Figure 4A, we observed that TCF/LEF reporter showed downregulation in $100 \mathrm{nM}$ FD-895 treated HeLa cells after $12 \mathrm{~h}$. We also investigated the effect of FD-895 and pladienolide B on mRNA expression of selected genes $L E F 1, F N 1$, and CCND1 [48-50] which involved in the $\mathrm{Wnt} / \beta$-catenin signaling pathway. The HeLa cells were exposed to $100 \mathrm{nM}$ of FD-895 or pladienolide B for different times and $L E F 1$, $C C N D 1$, and FN1 mRNA levels measured by qRTPCR. The expression of $L E F 1, C C N D 1$, and $F N 1$ was
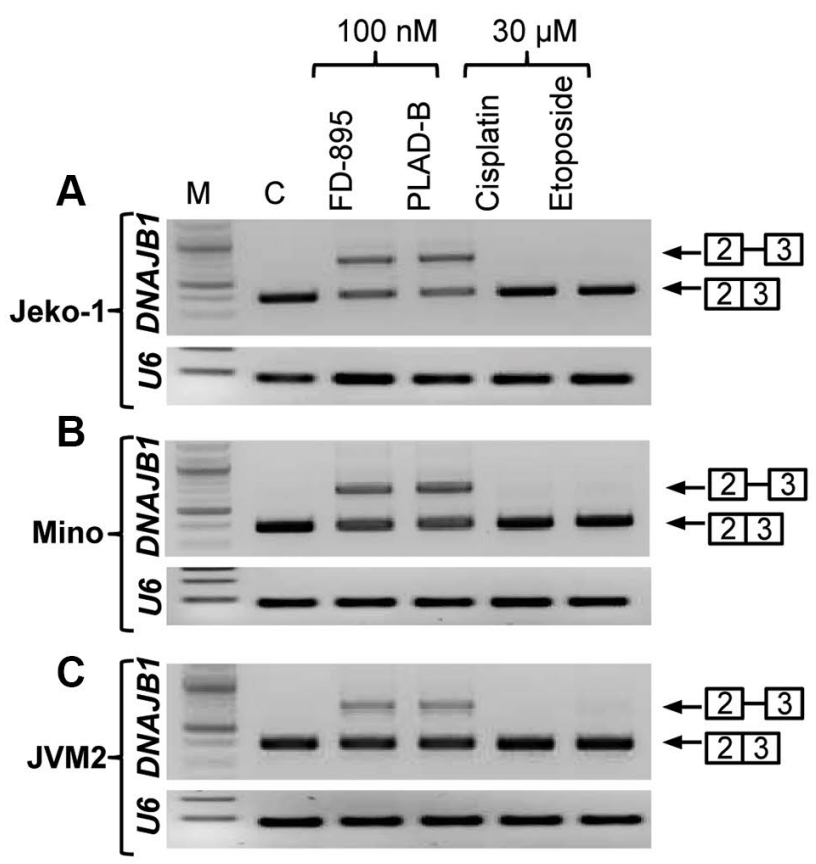

IR 2-3 DNAJB1 (597 bp) No IR 233 DNAJB1 (302 bp) significantly decreased by $8.33,6.25$, and 5.26 fold respectively (Figure 4B-4D) as the incubation period increased with the maximum level appearing at $20 \%$ at $24 \mathrm{~h}$. Further, we performed the RT-PCR to detect splicing in genes involved in Wnt signaling pathway like GSK3 $\beta$ and LRP5. HeLa cells treated with $100 \mathrm{nM}$ FD-895 showed weak IR in GSK3 $\beta$ and LRP5, an observation that was not observed in non-splicing controls $(30 \mu \mathrm{M}$ cisplatin). In comparisons to chemotherapy, the macrolides significantly downregulated the expression of GSK3 $\beta$ in HeLa cell line (Figure 4E). We then conducted Western blot analyses to study the correlation between mRNA and protein. Treatment with $100 \mathrm{nM}$ FD-895 or $100 \mathrm{nM}$ pladienolide $\mathrm{B}$ treatment resulted in the downregulation of $\beta$-catenin, LEF1, total LRP6, and phospho-LRP6 protein levels (Figure 4F). Altogether, the results from qRT-PCR and Western blot data demonstrate downregulation of key Wnt signaling pathway molecules in the HeLa cell line.

\section{Bioinformatics based gene-gene interaction}

Our next studies explored the effects of FD-895 and pladienolide B on select gene-gene interaction networks

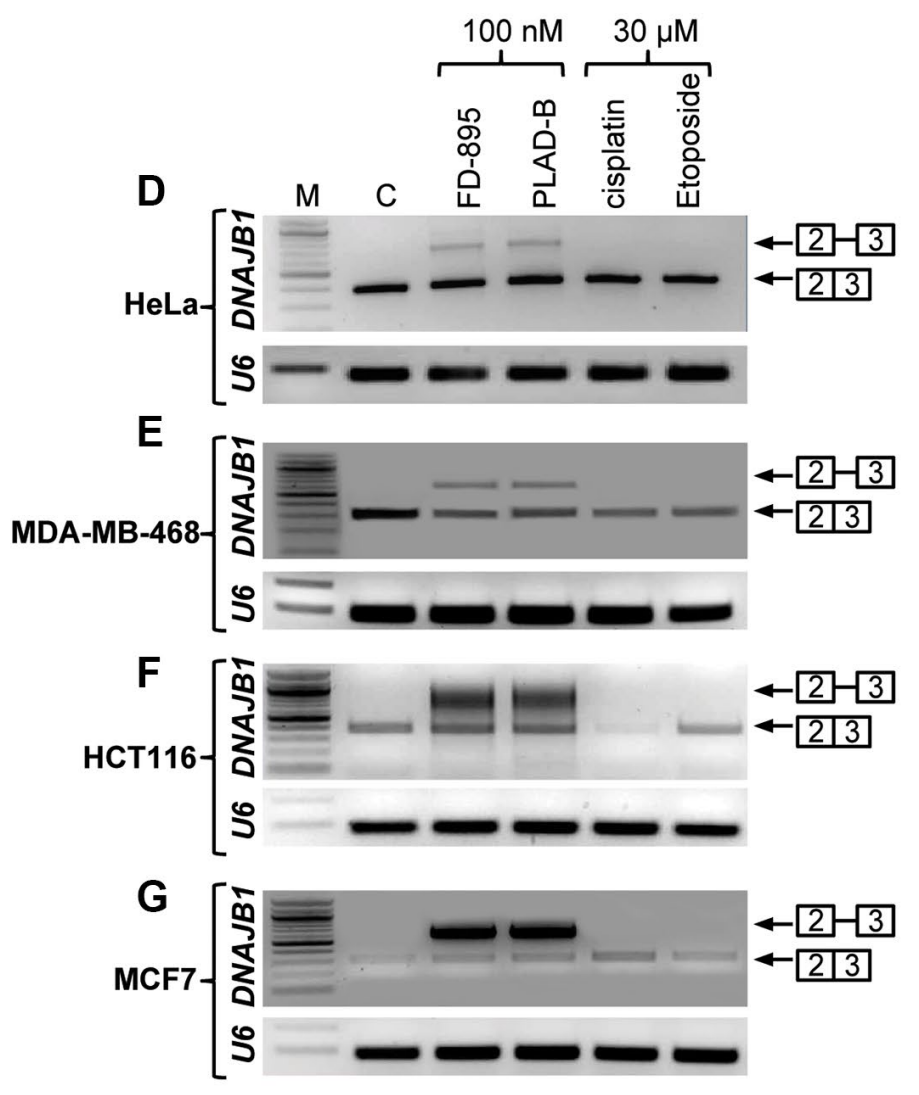

Figure 3. Intron retention of DNAJB1 gene in different cancer cell lines. Tumor cell lines were treated with $100 \mathrm{nM}$ of FD-895, 100 $\mathrm{nM}$ pladienolide $\mathrm{B}, 30 \mu \mathrm{M}$ cisplatin or $30 \mu \mathrm{M}$ etoposide for $4 \mathrm{~h}$. Analysis of IR of DNAJB1 mRNAs was evaluated by RT-PCR in (A-C) Mantle cell lymphoma cells, (Jeko-1, Mino and JMV-2), (D) HeLa, (E) MDA-MB-468 (F) HCT116 and (G) MCF-7 cells. RNU6A, an intronless gene was used as RNA quality and loading control. 
using GeneMANIA. We used DNAJB1, LEF1, $C T N N B 1, L R P 6$, and $S F 3 B 1$ as "Input" genes for genegene interaction analysis and included $S F 3 B 1$ in this analysis because SF3B1 is a component of the spliceosome-binding pocket of pladienolide B [51, 52]. As shown in Figure 5, we found the selected genes were

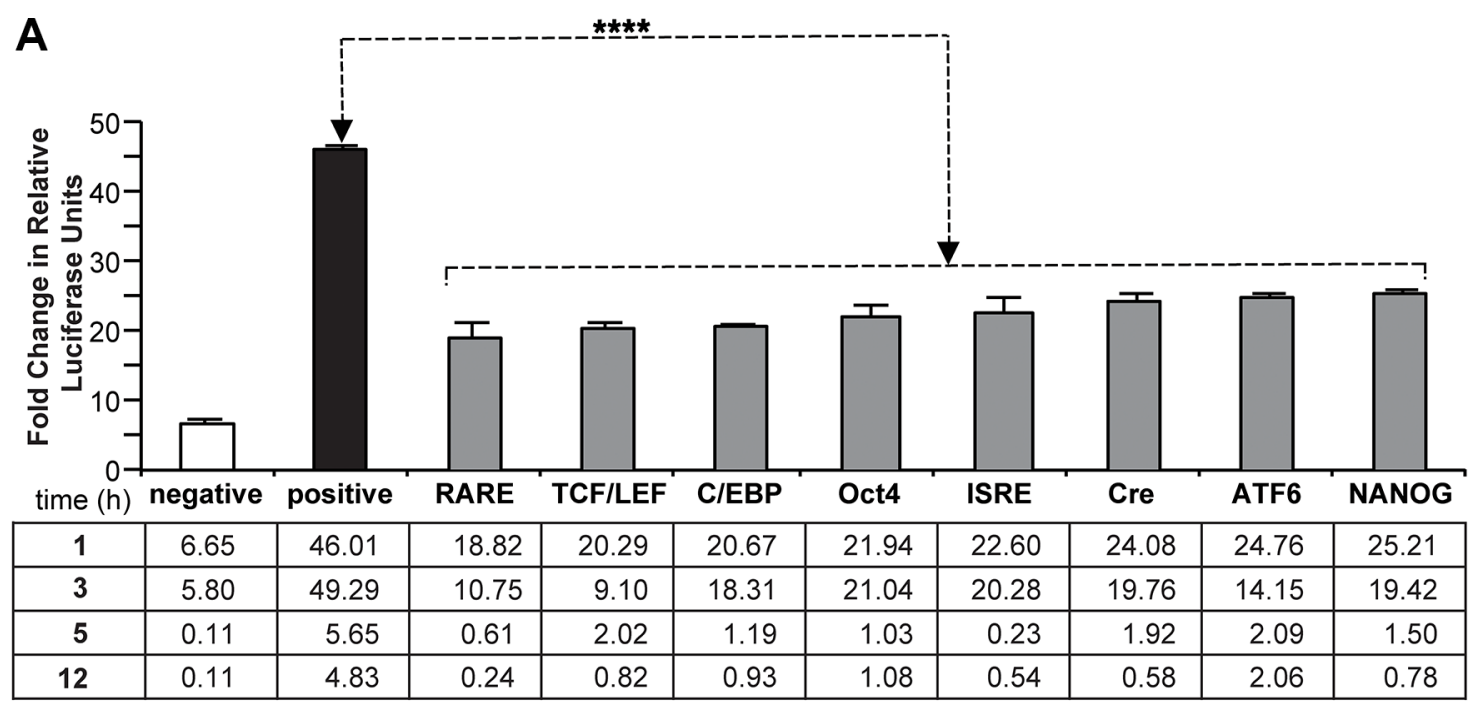

B

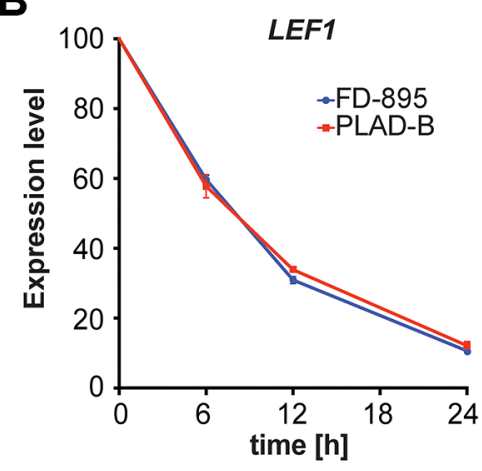

C

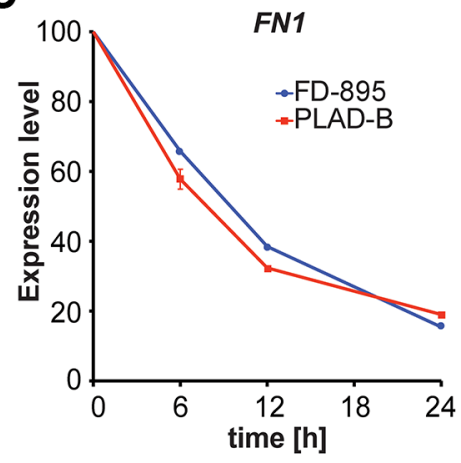

D

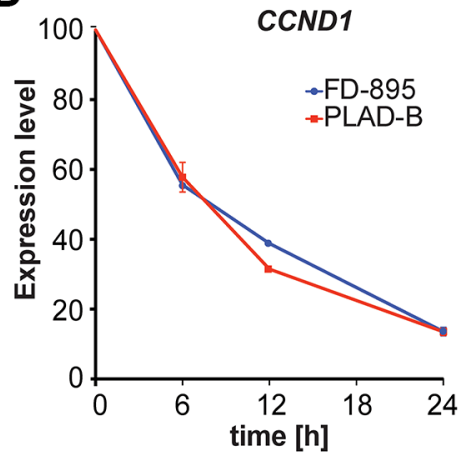

$\mathbf{E}$

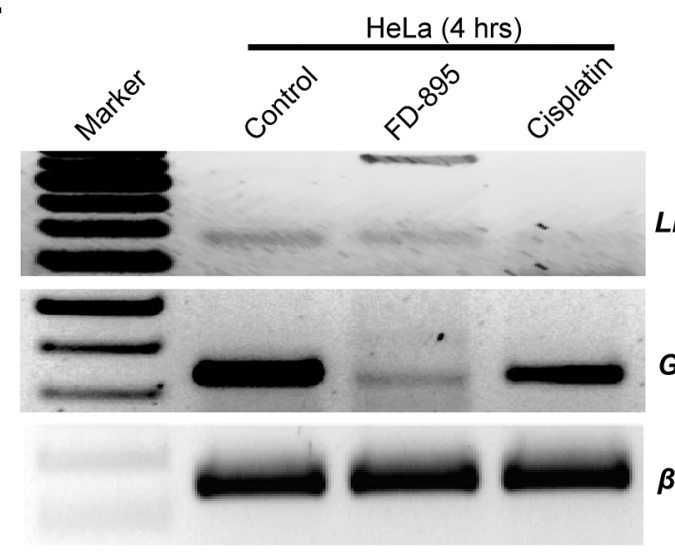

$\mathbf{F}$

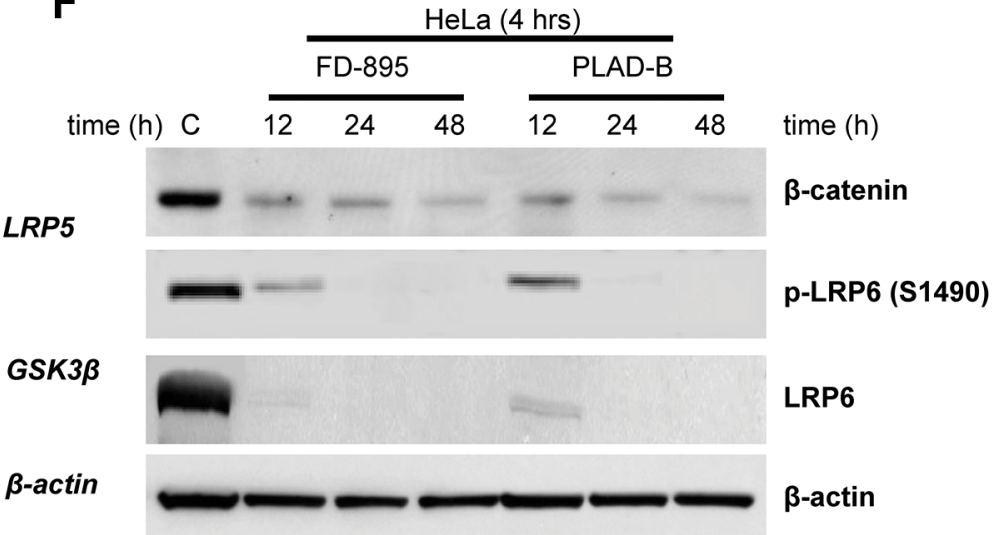

Figure 4. Effect of FD-895 on different pathways and effect on Wnt signaling in HeLa cells. (A) HeLa cells were use for introducing pathway reporters into cells via reverse transfection. Post-transfection, the cells were treated with vehicle or $100 \mathrm{nM}$ FD-895 for $3 \mathrm{~h}$. Luciferase and renilla expression was evaluated. HeLa cells were exposed to $100 \mathrm{nM}$ of FD-895 or $100 \mathrm{nM}$ pladienolide B for $6 \mathrm{~h}, 12$ $\mathrm{h}$ or $24 \mathrm{~h}$ and expression of (B) LEF1, (C) FN1, and (D) CCND1 were determined by qRT-PCR. (E) HeLa cells were treated with $100 \mathrm{nM}$ of FD895 or $30 \mu \mathrm{M}$ cisplatin for $4 \mathrm{~h}$. Analysis of IR for GSK3 $\beta$ and LRP5 mRNAs was evaluated by using RT-PCR. (F) HeLa cells were treated with $100 \mathrm{nM}$ of FD-895 or $100 \mathrm{nM}$ pladienolide B for $6 \mathrm{~h}, 12 \mathrm{~h}$ or $24 \mathrm{~h}$. Protein extracts were immunoblotted for $\beta$-catenin, phohspho-LRP6, LRP6, and $\beta$-actin. 
part of the network directly or indirectly associated with SF3B1.

We obtained total twenty genes from GeneMANIA analysis and among those top ten interactor molecule emerge in the network were based on the size of the circle including NELFE (negative elongation factor complex member E, rank-1), SF3B6 (splicing factor 3b subunit 6, rank-2), Wnt3A (Wnt family member 3A, rank-3), CTNNBIP1 (catenin beta interacting protein 1, rank-4), $C D X 1$ (caudal type homeobox 1, rank-5), $D K K 1$ (dickkopf Wnt signaling pathway inhibitor 1, rank-6), CTNNA1 (catenin alpha 1, rank-7), PIAS4 (protein inhibitor of activated STAT 4, rank-8), DKK4 (dickkopf Wnt signaling pathway inhibitor 4, rank-9), and TCF7L2 (transcription factor 7 like 2, rank-10). Among these genes few genes are involved in Wnt signaling such as Wnt3A, CTNNA1, DKK4, and TCF7L2 suggest that there is an important role of RNA splicing machinery in regulation of Wnt signaling pathway.

\section{DISCUSSION}

Splice modulation offers a unique opportunity to selectively modulate ongoing rapid cellular growth, and has shown early promise as a therapeutic target [53, 54]. Leveraging methods developed in prior studies in CLL, we tested in vitro activities of FD-895 and pladienolide $\mathrm{B}$ in solid tumor and mantle cell lymphoma cells. Here, our studies show that FD-895 and pladienolide B show potent apoptotic activity at nanomolar concentrations across the majority of cell lines screened. Both splice modulators demonstrated significant induction of apoptosis in human ovarian cancer cells, OV2008 and C13 (cisplatin resistant), and renal carcinoma.

Cell lines with mutant TP53 showed higher $\mathrm{IC}_{50}$ with FD-895 and pladienolide B. In the past study by our group, we observed that in the case of CLL patients harboring $17 \mathrm{pDEL} /$ TP53 mutations harboring CLL patients, the splice modulators were able to induce

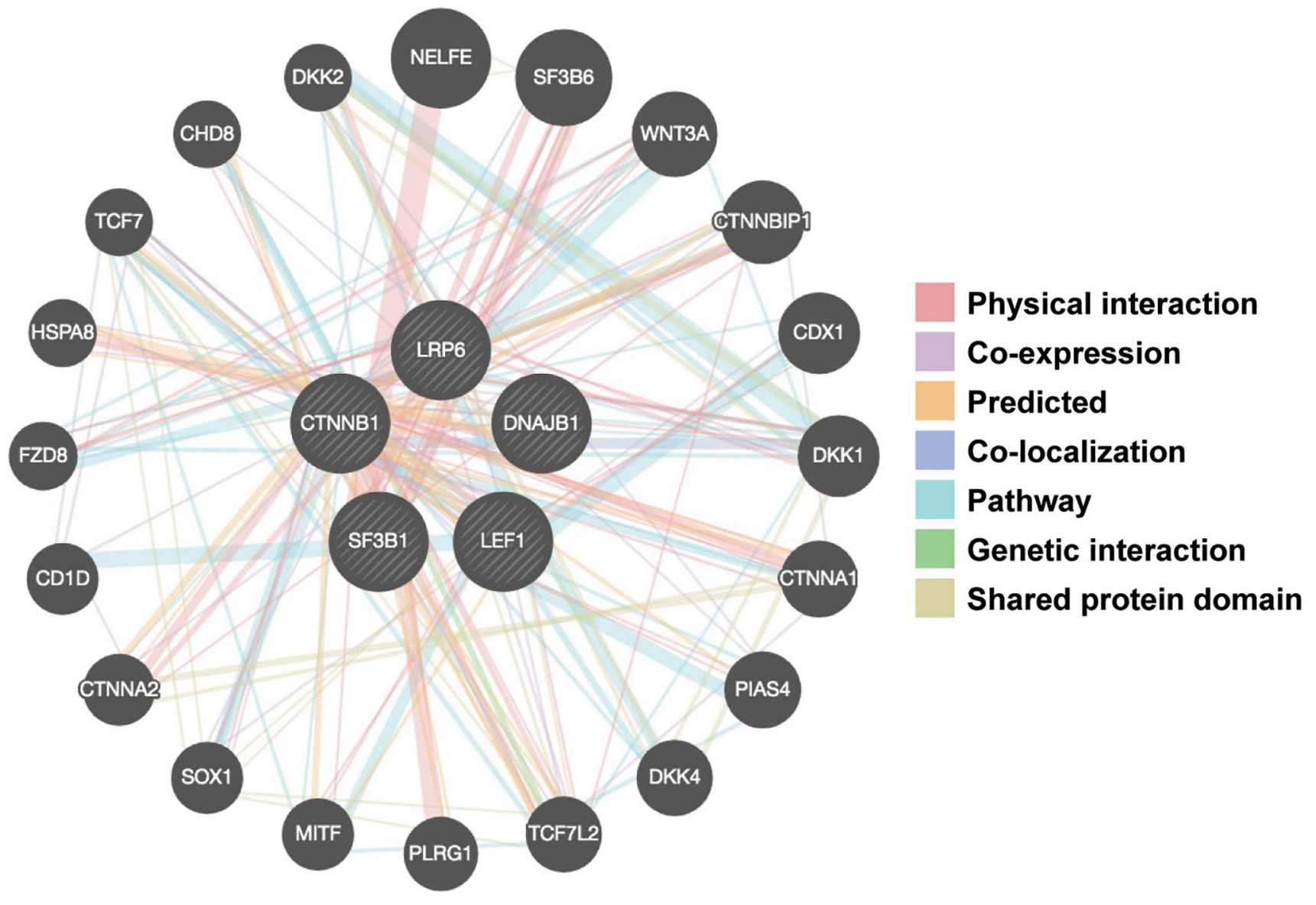

Figure 5. Gene-gene interaction networks among selected genes constructed by GeneMANIA. A gene-gene network was constructed with the search tool for the retrieval of interacting genes available in GeneMANIA annotation information for selected 5 genes, including physical interaction, genetic interaction, co-expression and shared pathways and protein structure domain. The central black nodes denote 5 selected genes used as an "INPUT", and peripheral nodes denote gene interactions with the black nodes. The network also contains 20 normal human genes. The size of the circles indicates the degree of interaction. 
in vitro cytotoxicity suggesting that the induction of cell death was TP53 independent. Splice modulators such as TG003 interfere with in the splicing machinery leading to TP53 activation, which induces TP53 accumulation, elevated p53 transcriptional activity, and p53-dependent $\mathrm{G}_{1}$ cell cycle arrest in U2OS (human osteosarcoma) and A375 (human melanoma) cell lines [55]. Further, in hepatocellular carcinoma (HCC), TP53 splice mutations have been associated with the development and progression of the disease [56]. These observations may differ in different malignancies due to behavior in the pathophysiology and the driving receptor/signaling pathway. This is important to note that not only studying alternative RNA splicing events such as IR, ES and A5'SS, A3'SS is crucial but the splice mutations and their impact on the development and pathophysiology of cancer could be of utmost significance.

Interestingly, FD-895 and pladienolide B spares and normal cell inducing PBMCs (include T cells, B cells, and NK cells, monocytes, and dendritic cells), suggesting that these compounds have a preference to induce in vitro cytotoxicity preferentially in cancer cells and this creates a beneficial therapeutic window for patient treatment. These findings were in concordance with our previous observations in normal B cells [30]. We also tested the normal cell line HEK-293 in response to FD-895 and found no significant cell death, which was different to the cytotoxicity induced by cisplatin. These data further corroborated our observation that SPLMs induce prudentially apoptosis in tumor cell lines, but not in normal cells $[57,58]$.

In other studies as well, HEK-293 cell line was also tested in vitro in response to isoginkgetin (splicing modulator control), a bioflavonoid derived from the leaves of Ginkgo biloba. In those studies, the propapoptotic activity induced by SPLMs including the isoginkgetin was significantly lower $[22,59,60]$.

Following in vitro cytotoxicity assays, we assessed if RNA splicing modulators induce IR in the different solid tumor as well as in mantle cell lymphoma cells. Using DNAJB1 has been used as a surrogate marker of splicing modulation; we found that FD-895 as well as pladienolide $\mathrm{B}$ induced IR in DNAJB1 in all the cell lines at $100 \mathrm{nM}[30,32]$.

Next, we turned our attention to identify the specific pathways regulated by these splice modulatory events. In HeLa cells, we observed that treatment with $100 \mathrm{nM}$ of FD-895 resulted in modulation of ATF6-C/EBP- $\beta$ signaling (ATF6 and C/EBP response elements), Wnt signaling (TCF/LEF reporter), type 1 interferon-induced signal transduction (ISRE reporter), CREB signaling
(cAMP response element, $\mathrm{CRE}$ is the response element), NANOG, and OCT4 pathways. The following discussion provides a brief overview of the significance of these pathways in their response to splice modulation by FD-895.

OCT4 is a homeodomain transcription factor of the POU family also known as POU5F1 (POU domain, class 5, transcription factor 1). It is involved in selfrenewal of undifferentiated embryonic stem cells and therefore used as a marker for dedifferentiation [61]. OCT4 is crucial for determination of fates of the inner mass and embryonic stem cells. OCT4 is capable of maintaining pluripotency throughout the embryonic development. It is also involved in proliferation of cancer cells including pancreatic, liver, testicular and lung cancer of adult germ cells [62].

In ATF6 pathway, the central player is ATF6 that works in a concentration dependent manner. At low levels, ATF6 activates the unfolded protein response (UPR) for self-defense. At high levels, it mediates apoptosis. ATF6 is crucial for transition from self-defense to selfdestruction of cells in endoplasmic reticulum (ER) stress [63].

In NANOG pathway, the NANOG transcription factor is important as it is involved in self-renewal regulation as well as maintenance of the embryonic stem cell pluripotency [64]. NANOG has been reported in number of malignancies including leukemia [65]. Both NANOG and OCT4 pathways are involved in regulation of pluripotency of stem cells [66].

We observed modulation of T-cell factor/lymphoid enhancer factor (TCF/LEF) in response to treatment with FD-895 in HeLa cell. Wnt alone led to an accumulation of $\beta$-catenin in the cytoplasm, but its nuclear activity is largely mediated by TCF/LEF only. $\mathrm{TCF} / \mathrm{LEF}$ is an important component of Wnt or Wnt/ $\beta$ catenin signaling pathway. The $\mathrm{Wnt} / \beta$-catenin signaling has been reported in a number of malignancies including cervical cancer $[67,68]$. Interestingly, we found that Wnt signaling pathway was downregulated after $12 \mathrm{~h}$ of FD-895 treatment. In human cells, Wnt is a secreted protein that acts as a ligand for ROR1 a receptor tyrosine kinase [69-71]. Wnt/ $\beta$-catenin activation occurs upon binding of Wnt5A with membranous proteins Frizzled (FZ) receptor and lysophosphatidic acid receptors (LRP5/6) protein. This binding event leads to recruitment of the scaffolding protein Disheveled (DVL), which results in phosphorylation of LRP5/6 receptors. During the course of these studies, we found that FD-895 reduced the expression of Wnt signaling pathway-associated transcripts including $L E F 1, F N 1, C C N D 1$, GSK3 $\beta$, and 
LRP5. LEF1 is a transcription factor that belong to the $\mathrm{T}$ cell Factor (TCF)/LEF family. LEF1 acts as nuclear effector in the $\mathrm{Wnt} / \beta$-catenin signaling pathway [72]. LEF1 mediates Wnt signaling pathway by through association with $\beta$-catenin [46].

Wnt/ $\beta$-catenin pathway requires the co-receptors LRP5 and LRP6 for activity. Post-translational modifications (PTMS) such as phosphorylation, methylation, acetylation, and sumoylation play a very important role in the pathophysiology of different malignancies. LRP5 is part of the signalosome complex is deregulated by cisplatin [73]. We also observed the same effect as we saw the non-intronic form of the LRP5 vanished upon treatment with cisplatin.

Phosphorylation of LRP6 is crucial for activation of Wnt/ $\beta$-catenin signaling as it can promote activation of Wnt signaling activation by recruiting casein kinase family proteins [74]. Targeting of LRP6 phosphorylation can inhibit $\mathrm{Wnt} / \beta$-catenin signaling [46].

The co-receptors for Wnt signaling, LRP5, and LRP6, have been revealed as potential oncogenic proteins. In human breast carcinoma, the expression of LRP6 is high [75]. Downregulation of LRP6 inhibits breast cancer tumorigenesis, whereas overexpression of LRP6 in the mouse mammary gland induces mammary hyperplasia [75, 76]. We observed that FD-895 downregulated LRP6 phosphorylation and causes the degradation of the LRP6 protein, an essential component of the Wnt receptor complex, promotes $\beta$ catenin degradation, and downregulation of LEF1 at the protein level. Therefore, we reasoned that FD-895 might block the phosphorylation of LRP6 that is required for initial Wnt signaling.

Glycogen synthase kinase-3 (GSK3) is an intracellular component of the Wnt pathway that can directly interact and phosphorylate LRP6. Glycogen synthase kinase $3 \beta$ (GSK3 $\beta$ ) is a crucial component of insulin and Wnt signaling pathways. PTMs particularly phosphorylation of EGFR in lung adenocarcinoma, and SF3B1 in CLL has been reported/targeted [31, 77]. We found that treatment with FD-895, but not by cisplatin lead to induction of IR in GSK3 $\beta$. An inactivated GSK3 $\beta$ could led to increased SNAIL activity and poor prognosis in cervical cancer [78].

Our results suggest that FD-895 not only modulate RNA splicing via induction of IR in genes such as $D N A J B 1$, but also inhibit $\mathrm{Wnt} / \beta$-catenin pathway via downregulation of $\beta$-catenin, LRP6, pLRP6, and LEF1. FD-895 can block LRP6 phosphorylation and cause degradation of LRP6 protein. Overall, this suggests that
LRP6 may also serve as a viable anticancer agent in these cell lines, particularly molecules that are capable of selectivity altering the phosphorylation of LRP6. Gene-gene interaction is very crucial for any pathway including Wnt signaling to study the interaction between them. We used GeneMANIA analysis to study the gene-gene interaction prediction with high accuracy [79], identified peripheral nodes corresponding to two genes. The output of analysis led to the identification of gene interactions involved in Wnt signaling ( Wnt $3 \mathrm{~A}$, CTNNBIP1, DKK1, and DKK4), as well as in RNA splicing $(S F 3 B 6$, and $N E L F E)$. Among those, there were genes such as $S F 3 B 6$, a gene indirectly interact with $S F 3 B 1$ is an integral part of the spliceosome complex. $S F 3 B 6$ has been reported to be associated with p53 activity in human non-small cell lung carcinoma [80]. The applications of SPLMs such as E7107, and H3B-8800 have been explored in different clinical trials for therapeutic purposes. The phase I clinical trial at M D Anderson enrolled 26 patients with solid tumors who received escalating doses starting 0.6 $\mathrm{mg} / \mathrm{m}^{2}$ intravenous infusion on days 1 and 8 and the cycle was repeated every 21 days. The stable disease was observed in $31 \%$ of patients. The major AE was the development of acute blindness, which led to the discontinuation of the trial [28]. Similar AE was observed in the Dutch trial on E7107, where reversible grade 4-blurred vision was observed in one patient [29]. Both E7107 trials were suspended due to blindness as one of the AE. H3B-8800, which is an orally available small molecule modulator that binds to SF3B-complex and leads to changes in the alternate RNA splicing in the target cells [81], and induce cell death in the spliceosome-mutant cancers [82] via IR of GC-rich introns that are enriched for genes encoding spliceosome components. H3B-8800 approved for testing in Phase 1 (NCT02841540), open-label, first-inhuman (FIH) study design to evaluate the safety, tolerability, pharmacokinetics (PK), pharmacodynamics (PD), and preliminary antitumor activity in MDS, AML, and CMML. Additionally, the application of PLAD-B and FD-895 at in vitro and in vivo levels showed promising results in current and previous studies by different groups. These studies are clinically relevant because one hand where $\mathrm{nM}$ concentration is required to achieve $\mathrm{IC}_{50}$ in the cancerous cell lines. In contrast, supra-physiological concentration is necessary for normal cells, suggesting a good therapeutic window for treatment options using these SPLMs in conjunction with the current chemotherapy like cisplatin and etoposide. As far as the standalone versus combination therapy is concerned, though we have not assessed the potential of FD895/Pladienolide- B in combination with an inhibitor of BCL-2 family members, but at the same time there are studies where a combination of splicing inhibitors 
meayamycin B with ABT-737 (Bcl-xL inhibitor) led to apoptosis in non-small cell lung cancer cell lines (A549 and H1299) [83]. A combination of other SPLMs spliceostatin A (SSA) with either ABT-263 or ABT199 (both are $\mathrm{Bcl}-2 / \mathrm{Bcl}-\mathrm{xL}$ antagonists) led to apoptosis in CLL-B cells [17]. Another example of combination approach where either Sudemycins C, D1, or D6 with BTK inhibitor (ibrutinib) inhibitor led to induction of cell death in CLL-B cells further suggests that synergistic effect can be achieved by combining the SPLMs with different inhibitors to induce cell death via modulation of signaling and apoptotic machinery associated pathways. For using stand-alone SPLMs, it is important to know the effect of the SPLMs on the genes/transcripts essential for normal/vital functioning of the body as in the past using E7101 in two clinical trials acute blindness was observed in patients with different malignancies [28, 29].

Collectively, the outcome of the trials, and data generated using other SPLMs; suggest that there is potential in modulating or selectively inhibiting the spliceosome machinery to achieve therapeutic potential in different malignancies including hematologic and solid cancers.

\section{CONCLUSION}

In summary, our results suggest that both FD-895 and pladienolide $\mathrm{B}$ demonstrated in vitro toxicity in different malignancies, spared normal PBMCs, and modulates mRNA splicing. It also exerts selective toxicity to malignant cells compared with normal cells. Furthermore, we showed that FD-895 (pladienolide B was not explored) able to modulate the posttranslational events as suggested by downregulation of LRP6 phosphorylation and expression of associated Wnt target genes. This data suggests that these splice modulators could be useful in targeting malignancies where Wnt/ $\beta$-catenin play an important role by inhibiting mRNA splicing and LRP6 phosphorylation. These results showed that these compounds not only modulate mRNA splicing in CLL, but also in mantle cell lymphoma, and solid tumors of colon, breast, ovarian, and renal origin. Overall this study demonstrates that FD-895 and pladienolide B modulate splicing machinery and result in downstream regulation of signaling pathways, including the $\mathrm{Wnt} / \beta$-catenin pathway. Furthermore, the in vitro efficacy of FD-895 and pladienolide $\mathrm{B}$ was found to be superior to conventional chemotherapy as indicated in a wide range of malignant cell lines of colon, breast, ovarian, renal, and cervical origin. Further, there is a need for extensive research not only at in vitro but in vivo levels to assess synergistically the ability of splice modulators with conventional chemotherapy agents like cisplatin and etoposide to assess their potential as a combination or synergistic treatments.

\section{Abbreviations}

CCND1: Cyclin D1; CTNNB1: Catenin, beta-1; CLL: Chronic lymphocytic leukemia; DLT: Dose limiting toxicity; FBS: Fetal bovine serum; FN1: Fibronectin 1; GeneMANIA: Gene Multiple Association Network Integration Algorithm; GSK3: Glycogen synthase kinase-3; IR: Intron retention; LEF1: Lymphoid enhancer-binding factor-1; LRP6: LDL Receptor Related Protein 6; MCL: Mantle cell lymphoma; MTD: Maximum tolerated dose; PBMCs: Peripheral blood mononuclear cells; RT-PCR: Reverse transcriptase PCR; SF3B1: Splicing Factor 3b Subunit 1; SPLMs: Splicing modulators; SRSF2: Serine And Arginine Rich Splicing Factor 2; U2AF1: U2 Small Nuclear RNA Auxiliary Factor 1.

\section{AUTHOR CONTRIBUTIONS}

DK performed cell culture, cell proliferation, RT-PCR, qRT-PCR with assistance of ZH, and IS. DK performed Western blot and Flow cytometer with assistance of MKK. MKK carried out the bioinformatics analysis. DK, and MKK analyzed and interpreted the data, and wrote the manuscript. DK wrote the first draft of the manuscript and prepared draft of the figures. DK, MKK, JJL, MDB, and JEC edited the manuscript. JJL, and RV, and MDB prepared the samples of FD-895 used within this program. TJK and JEC provided regents, chemotherapeutic agents and cell lines data. JEC, and DK conceived and guided the research. All authors read and approved the final manuscript.

\section{ACKNOWLEDGMENTS}

The funders had no role in study design, data collection and analysis, decision to publish, or preparation of the manuscript.

\section{CONFLICTS OF INTEREST}

The authors declare no conflicts of interest related to this study.

\section{FUNDING}

This work was supported by grant 285871 from the Lymphoma Research Foundation (LRF) to JEC, and MDB, the American Cancer Society (RSG-06-011-01$\mathrm{CDD}$ ) to $\mathrm{MDB}$, the National Institutes of Health (PO1CA081534)-CLL research consortium grant to JEC. MKK is the recipient of the TARE fellowship 
(TAR/2018/001054) from the Science and Engineering Research Board (SERB), Department of Science and Technology, Government of India and the study partly supported by the research grants to MKK (sanction \#: 5/13/55/2020/NCD-III) from ICMR, New Delhi, India.

\section{REFERENCES}

1. Wang BD, Lee NH. Aberrant RNA Splicing in Cancer and Drug Resistance. Cancers (Basel). 2018; 10:458. https://doi.org/10.3390/cancers10110458 PMID: $\underline{30463359}$

2. Tripathi G, Tripathi A, Johnson J, Kashyap MK. Role of RNA Splicing in Regulation of Cancer Stem Cell. Curr Stem Cell Res Ther. 2021. [Epub ahead of print]. https://doi.org/10.2174/1574888X166662112071036 $\underline{28}$ PMID:34875992

3. León B, Kashyap MK, Chan WC, Krug KA, Castro JE, La Clair JJ, Burkart MD. A Challenging Pie to Splice: Drugging the Spliceosome. Angew Chem Int Ed Engl. 2017; 56:12052-63.

https://doi.org/10.1002/anie.201701065 PMID: $\underline{28371109}$

4. Jutzi D, Akinyi MV, Mechtersheimer J, Frilander MJ, Ruepp MD. The emerging role of minor intron splicing in neurological disorders. Cell Stress. 2018; 2:40-54. https://doi.org/10.15698/cst2018.03.126 PMID: $\underline{31225466}$

5. Chen W, Moore MJ. The spliceosome: disorder and dynamics defined. Curr Opin Struct Biol. 2014; 24:141-9.

https://doi.org/10.1016/i.sbi.2014.01.009 PMID:24530854

6. Bonnal S, Vigevani L, Valcárcel J. The spliceosome as a target of novel antitumour drugs. Nat Rev Drug Discov. 2012; 11:847-59. https://doi.org/10.1038/nrd3823 PMID:23123942

7. Wang L, Lawrence MS, Wan $Y$, Stojanov $P$, Sougnez $C$, Stevenson K, Werner L, Sivachenko A, DeLuca DS, Zhang L, Zhang W, Vartanov AR, Fernandes SM, et al. SF3B1 and other novel cancer genes in chronic lymphocytic leukemia. N Engl J Med. 2011; 365:2497506.

https://doi.org/10.1056/NEJMoa1109016 PMID:22150006

8. Harbour JW, Roberson ED, Anbunathan H, Onken MD, Worley LA, Bowcock AM. Recurrent mutations at codon 625 of the splicing factor SF3B1 in uveal melanoma. Nat Genet. 2013; 45:133-5.

https://doi.org/10.1038/ng.2523

PMID:23313955
9. Papaemmanuil E, Gerstung M, Malcovati L, Tauro $S$, Gundem G, Van Loo P, Yoon CJ, Ellis P, Wedge DC, Pellagatti A, Shlien A, Groves MJ, Forbes SA, et al, and Chronic Myeloid Disorders Working Group of the International Cancer Genome Consortium. Clinical and biological implications of driver mutations in myelodysplastic syndromes. Blood. 2013; 122:361627.

https://doi.org/10.1182/blood-2013-08-518886 PMID:24030381

10. Finci $L I$, Zhang $X$, Huang $X$, Zhou $Q$, Tsai J, Teng $T$, Agrawal A, Chan B, Irwin S, Karr C, Cook A, Zhu P, Reynolds $D$, et al. The cryo-EM structure of the SF3b spliceosome complex bound to a splicing modulator reveals a pre-mRNA substrate competitive mechanism of action. Genes Dev. 2018; 32:309-20. https://doi.org/10.1101/gad.311043.117 PMID:29491137

11. Cretu C, Agrawal AA, Cook A, Will CL, Fekkes P, Smith PG, Lührmann R, Larsen N, Buonamici S, Pena V. Structural Basis of Splicing Modulation by Antitumor Macrolide Compounds. Mol Cell. 2018; 70:26573.e8.

https://doi.org/10.1016/i.molcel.2018.03.011 PMID:29656923

12. van der Werf I, Wojtuszkiewicz A, Yao H, Sciarrillo R, Meggendorfer M, Hutter S, Walter W, Janssen J, Kern W, Haferlach C, Haferlach T, Jansen G, Kaspers GJL, et al. SF3B1 as therapeutic target in FLT3/ITD positive acute myeloid leukemia. Leukemia. 2021; 35:2698702.

https://doi.org/10.1038/s41375-021-01273-7 PMID: $\underline{34002025}$

13. Popli P, Richters MM, Chadchan SB, Kim TH, Tycksen E, Griffith $O$, Thaker PH, Griffith M, Kommagani R. Splicing factor SF3B1 promotes endometrial cancer progression via regulating KSR2 RNA maturation. Cell Death Dis. 2020; 11:842.

https://doi.org/10.1038/s41419-020-03055-y PMID:33040078

14. López-Cánovas JL, Del Rio-Moreno M, GarcíaFernandez $\mathrm{H}$, Jiménez-Vacas JM, Moreno-Montilla MT, Sánchez-Frias ME, Amado V, L-López F, Fondevila MF, Ciria R, Gómez-Luque I, Briceño J, Nogueiras R, et al. Splicing factor SF3B1 is overexpressed and implicated in the aggressiveness and survival of hepatocellular carcinoma. Cancer Lett. 2021; 496:72-83.

https://doi.org/10.1016/i.canlet.2020.10.010 PMID:33038489

15. Nakajima H, Hori Y, Terano H, Okuhara M, Manda T, Matsumoto S, Shimomura K. New antitumor substances, FR901463, FR901464 and FR901465. II. 
Activities against experimental tumors in mice and mechanism of action. J Antibiot (Tokyo). 1996; 49:1204-11.

https://doi.org/10.7164/antibiotics.49.1204 PMID: 9031665

16. Kaida D, Motoyoshi H, Tashiro E, Nojima T, Hagiwara M, Ishigami K, Watanabe $H$, Kitahara $T$, Yoshida $T$, Nakajima H, Tani T, Horinouchi S, Yoshida M. Spliceostatin A targets SF $3 b$ and inhibits both splicing and nuclear retention of pre-mRNA. Nat Chem Biol. 2007; 3:576-83.

https://doi.org/10.1038/nchembio.2007.18 PMID:17643111

17. Larrayoz M, Blakemore SJ, Dobson RC, Blunt MD, Rose-Zerilli MJ, Walewska R, Duncombe A, Oscier D, Koide K, Forconi F, Packham G, Yoshida M, Cragg MS, et al. The SF3B1 inhibitor spliceostatin A (SSA) elicits apoptosis in chronic lymphocytic leukaemia cells through downregulation of Mcl-1. Leukemia. 2016; 30:351-60.

https://doi.org/10.1038/leu.2015.286

PMID:26488112

18. Puthenveetil $\mathrm{S}$, He H, Loganzo F, Musto $S$, Teske J, Green M, Tan X, Hosselet C, Lucas J, Tumey LN, Sapra $P$, Subramanyam C, O'Donnell CJ, Graziani El. Multivalent peptidic linker enables identification of preferred sites of conjugation for a potent thialanstatin antibody drug conjugate. PLoS One. 2017; 12:e0178452.

https://doi.org/10.1371/journal.pone.0178452 PMID:28558059

19. Gao $Y$, Trivedi S, Ferris RL, Koide K. Regulation of HPV16 E6 and MCL1 by SF3B1 inhibitor in head and neck cancer cells. Sci Rep. 2014; 4:6098.

https://doi.org/10.1038/srep06098

PMID:25139387

20. Yoon SO, Shin S, Lee HJ, Chun HK, Chung AS. Isoginkgetin inhibits tumor cell invasion by regulating phosphatidylinositol 3-kinase/Akt-dependent matrix metalloproteinase-9 expression. Mol Cancer Ther. 2006; 5:2666-75.

https://doi.org/10.1158/1535-7163.MCT-06-0321 PMID:17121913

21. Makowski K, Vigevani L, Albericio F, Valcárcel J, Álvarez M. Sudemycin K: A Synthetic Antitumor Splicing Inhibitor Variant with Improved Activity and Versatile Chemistry. ACS Chem Biol. 2017; 12:163-73. https://doi.org/10.1021/acschembio.6b00562 PMID:28103691

22. Fan L, Lagisetti C, Edwards CC, Webb TR, Potter PM. Sudemycins, novel small molecule analogues of FR901464, induce alternative gene splicing. ACS Chem Biol. 2011; 6:582-9. https://doi.org/10.1021/cb100356k

PMID:21344922

23. Hasegawa M, Miura T, Kuzuya K, Inoue A, Won Ki S, Horinouchi S, Yoshida T, Kunoh T, Koseki K, Mino K, Sasaki R, Yoshida M, Mizukami T. Identification of SAP155 as the target of GEX1A (Herboxidiene), an antitumor natural product. ACS Chem Biol. 2011; 6:229-33.

https://doi.org/10.1021/cb100248e

PMID:21138297

24. Corrionero A, Miñana B, Valcárcel J. Reduced fidelity of branch point recognition and alternative splicing induced by the anti-tumor drug spliceostatin A. Genes Dev. 2011; 25:445-59.

https://doi.org/10.1101/gad.2014311

PMID:21363963

25. Wu G, Fan L, Edmonson MN, Shaw T, Boggs K, Easton J, Rusch MC, Webb TR, Zhang J, Potter PM. Inhibition of SF3B1 by molecules targeting the spliceosome results in massive aberrant exon skipping. RNA. 2018; 24:1056-66.

https://doi.org/10.1261/rna.065383.117

PMID:29844105

26. Vigevani L, Gohr A, Webb T, Irimia M, Valcárcel J. Molecular basis of differential 3' splice site sensitivity to anti-tumor drugs targeting U2 snRNP. Nat Commun. 2017; 8:2100. https://doi.org/10.1038/s41467-017-02007-z PMID:29235465

27. Thurman M, van Doorn J, Danzer B, Webb TR, Stamm $S$. Changes in Alternative Splicing as Pharmacodynamic Markers for Sudemycin D6. Biomark Insights. 2017; 12:1177271917730557. https://doi.org/10.1177/1177271917730557 PMID:28932105

28. Hong DS, Kurzrock R, Naing A, Wheler JJ, Falchook GS, Schiffman JS, Faulkner N, Pilat MJ, O'Brien J, LoRusso P. A phase I, open-label, single-arm, dose-escalation study of E7107, a precursor messenger ribonucleic acid (pre-mRNA) splicesome inhibitor administered intravenously on days 1 and 8 every 21 days to patients with solid tumors. Invest New Drugs. 2014; 32:436-44.

https://doi.org/10.1007/s10637-013-0046-5 PMID:24258465

29. Eskens FA, Ramos FJ, Burger H, O'Brien JP, Piera A, de Jonge MJ, Mizui Y, Wiemer EA, Carreras MJ, Baselga J, Tabernero J. Phase I pharmacokinetic and pharmacodynamic study of the first-in-class spliceosome inhibitor E7107 in patients with advanced solid tumors. Clin Cancer Res. 2013; 19:6296-304. https://doi.org/10.1158/1078-0432.CCR-13-0485 PMID:23983259 
30. Kashyap MK, Kumar D, Villa R, La Clair JJ, Benner C, Sasik R, Jones H, Ghia EM, Rassenti LZ, Kipps TJ, Burkart MD, Castro JE. Targeting the spliceosome in chronic lymphocytic leukemia with the macrolides FD-895 and pladienolide-B. Haematologica. 2015; 100:945-54.

https://doi.org/10.3324/haematol.2014.122069

PMID:25862704

31. Kumar D, Kashyap MK, La Clair JJ, Villa R, Spaanderman I, Chien S, Rassenti LZ, Kipps TJ, Burkart MD, Castro JE. Selectivity in Small Molecule Splicing Modulation. ACS Chem Biol. 2016; 11:2716-23. https://doi.org/10.1021/acschembio.6b00399 PMID:27499047

32. Villa R, Kashyap MK, Kumar D, Kipps TJ, Castro JE, La Clair JJ, Burkart MD. Stabilized cyclopropane analogs of the splicing inhibitor FD-895. J Med Chem. 2013; 56:6576-82.

https://doi.org/10.1021/jm400861t

PMID:23919277

33. Kashyap MK, Kumar $\mathrm{D}$, Jones $\mathrm{H}$, Amaya-Chanaga $\mathrm{Cl}$, Choi MY, Melo-Cardenas J, Ale-Ali A, Kuhne MR, Sabbatini P, Cohen LJ, Shelat SG, Rassenti LZ, Kipps TJ, et al. Ulocuplumab (BMS-936564 / MDX1338): a fully human anti-CXCR4 antibody induces cell death in chronic lymphocytic leukemia mediated through a reactive oxygen species-dependent pathway. Oncotarget. 2016; 7:2809-22.

https://doi.org/10.18632/oncotarget.6465

PMID:26646452

34. Lu D, Choi MY, Yu J, Castro JE, Kipps TJ, Carson DA. Salinomycin inhibits Wnt signaling and selectively induces apoptosis in chronic lymphocytic leukemia cells. Proc Natl Acad Sci U S A. 2011; 108:13253-7.

https://doi.org/10.1073/pnas.1110431108

PMID:21788521

35. Livak KJ, Schmittgen TD. Analysis of relative gene expression data using real-time quantitative PCR and the 2(-Delta Delta C(T)) Method. Methods. 2001; 25:402-8.

https://doi.org/10.1006/meth.2001.1262

PMID: 11846609

36. Bradford MM. A rapid and sensitive method for the quantitation of microgram quantities of protein utilizing the principle of protein-dye binding. Anal Biochem. 1976; 72:248-54.

https://doi.org/10.1006/abio.1976.9999

PMID:942051

37. Warde-Farley D, Donaldson SL, Comes O, Zuberi K, Badrawi R, Chao P, Franz M, Grouios C, Kazi F, Lopes CT, Maitland A, Mostafavi S, Montojo J, et al. The GeneMANIA prediction server: biological network integration for gene prioritization and predicting gene function. Nucleic Acids Res. 2010; 38:W214-20.

https://doi.org/10.1093/nar/gkq537

PMID:20576703

38. Damia G, Broggini M. Platinum Resistance in Ovarian Cancer: Role of DNA Repair. Cancers (Basel). 2019; 11:119.

https://doi.org/10.3390/cancers11010119

PMID:30669514

39. Singh N, Bhakuni R, Chhabria D, Kirubakaran S. MDC1 depletion promotes cisplatin induced cell death in cervical cancer cells. BMC Res Notes. 2020; 13:146.

https://doi.org/10.1186/s13104-020-04996-5 PMID: $\underline{32160908}$

40. Li H, Ma X, Yang D, Suo Z, Dai R, Liu C. PCAT-1 contributes to cisplatin resistance in gastric cancer through epigenetically silencing PTEN via recruiting EZH2. J Cell Biochem. 2020; 121:1353-61.

https://doi.org/10.1002/jcb.29370

PMID:31478258

41. Nomura T, Yamasaki $M$, Nomura $Y$, Mimata $H$. Expression of the inhibitors of apoptosis proteins in cisplatin-resistant prostate cancer cells. Oncol Rep. 2005; 14:993-7.

PMID: $\underline{16142363}$

42. Galluzzi L, Vitale I, Michels J, Brenner C, Szabadkai G, Harel-Bellan A, Castedo M, Kroemer G. Systems biology of cisplatin resistance: past, present and future. Cell Death Dis. 2014; 5:e1257.

https://doi.org/10.1038/cddis.2013.428

PMID:24874729

43. Yang Z, Liao J, Carter-Cooper BA, Lapidus RG, Cullen $\mathrm{KJ}$, Dan H. Regulation of cisplatin-resistant head and neck squamous cell carcinoma by the SRC/ETS-1 signaling pathway. BMC Cancer. 2019; 19:485. https://doi.org/10.1186/s12885-019-5664-7 PMID: $\underline{31118072}$

44. Parvez S, Long MJ, Lin HY, Zhao Y, Haegele JA, Pham VN, Lee DK, Aye Y. T-REX on-demand redox targeting in live cells. Nat Protoc. 2016; 11:2328-56.

https://doi.org/10.1038/nprot.2016.114

PMID:27809314

45. Sumithra B, Saxena U, Das AB. Alternative splicing within the Wnt signaling pathway: role in cancer development. Cell Oncol (Dordr). 2016; 39:1-13. https://doi.org/10.1007/s13402-015-0266-0 PMID:26762488

46. Ramos-Solano M, Meza-Canales ID, Torres-Reyes LA, Alvarez-Zavala M, Alvarado-Ruíz L, Rincon-Orozco B, Garcia-Chagollan $M$, Ochoa-Hernández $A B$, OrtizLazareno PC, Rösl F, Gariglio P, Jave-Suárez LF, 
Aguilar-Lemarroy A. Expression of WNT genes in cervical cancer-derived cells: Implication of WNT7A in cell proliferation and migration. Exp Cell Res. 2015; 335:39-50.

https://doi.org/10.1016/i.yexcr.2015.05.001 PMID:25978974

47. Wu D, Pan W. GSK3: a multifaceted kinase in Wnt signaling. Trends Biochem Sci. 2010; 35:161-8. https://doi.org/10.1016/i.tibs.2009.10.002 PMID:19884009

48. Tiemessen MM, Baert MR, Schonewille $T$, Brugman $\mathrm{MH}$, Famili F, Salvatori DC, Meijerink JP, Ozbek U, Clevers $H$, van Dongen JJ, Staal FJ. The nuclear effector of Wnt-signaling, Tcf1, functions as a T-cellspecific tumor suppressor for development of lymphomas. PLoS Biol. 2012; 10:e1001430. https://doi.org/10.1371/journal.pbio.1001430 PMID:23185135

49. Hlubek F, Brabletz T, Budczies J, Pfeiffer S, Jung A, Kirchner T. Heterogeneous expression of Wnt/betacatenin target genes within colorectal cancer. Int J Cancer. 2007; 121:1941-8. https://doi.org/10.1002/ijc.22916 PMID:17631641

50. Lu D, Zhao Y, Tawatao R, Cottam HB, Sen M, Leoni LM, Kipps TJ, Corr M, Carson DA. Activation of the Wnt signaling pathway in chronic lymphocytic leukemia. Proc Natl Acad Sci U S A. 2004; 101:311823.

https://doi.org/10.1073/pnas.0308648100 PMID:14973184

51. Zhang $Q$, Di C, Yan J, Wang F, Qu T, Wang Y, Chen Y, Zhang $X$, Liu $Y$, Yang $H$, Zhang $H$. Inhibition of SF3b1 by pladienolide $\mathrm{B}$ evokes cycle arrest, apoptosis induction and p73 splicing in human cervical carcinoma cells. Artif Cells Nanomed Biotechnol. 2019; 47:1273-80.

https://doi.org/10.1080/21691401.2019.1596922 PMID: $\underline{30963795}$

52. Aouida M, Eid A, Mahfouz MM. CRISPR/Cas9mediated target validation of the splicing inhibitor Pladienolide B. Biochim Open. 2016; 3:72-5. https://doi.org/10.1016/i.biopen.2016.02.001 PMID:29450134

53. Oltean S, Bates DO. Hallmarks of alternative splicing in cancer. Oncogene. 2014; 33:5311-8. https://doi.org/10.1038/onc.2013.533 PMID:24336324

54. Eswaran J, Horvath A, Godbole S, Reddy SD, Mudvari P, Ohshiro K, Cyanam D, Nair S, Fuqua SA, Polyak K, Florea LD, Kumar R. RNA sequencing of cancer reveals novel splicing alterations. Sci Rep. 2013; 3:1689. https://doi.org/10.1038/srep01689

PMID:23604310

55. Allende-Vega N, Dayal S, Agarwala U, Sparks A, Bourdon JC, Saville MK. p53 is activated in response to disruption of the pre-mRNA splicing machinery. Oncogene. 2013; 32:1-14.

https://doi.org/10.1038/onc.2012.38

PMID:22349816

56. Lai MY, Chang HC, Li HP, Ku CK, Chen PJ, Sheu JC, Huang GT, Lee PH, Chen DS. Splicing mutations of the p53 gene in human hepatocellular carcinoma. Cancer Res. 1993; 53:1653-6.

PMID:8384081

57. Florea AM, Büsselberg D. Cisplatin as an anti-tumor drug: cellular mechanisms of activity, drug resistance and induced side effects. Cancers (Basel). 2011; 3:1351-71.

https://doi.org/10.3390/cancers3011351

PMID:24212665

58. Price PM, Yu F, Kaldis P, Aleem E, Nowak G, Safirstein $\mathrm{RL}$, Megyesi J. Dependence of cisplatin-induced cell death in vitro and in vivo on cyclin-dependent kinase 2. J Am Soc Nephrol. 2006; 17:2434-42. https://doi.org/10.1681/ASN.2006020162 PMID: 16914540

59. O'Brien K, Matlin AJ, Lowell AM, Moore MJ. The biflavonoid isoginkgetin is a general inhibitor of PremRNA splicing. J Biol Chem. 2008; 283:33147-54. https://doi.org/10.1074/jbc.M805556200 PMID: 18826947

60. Lagisetti C, Pourpak A, Goronga T, Jiang Q, Cui X, Hyle J, Lahti JM, Morris SW, Webb TR. Synthetic mRNA splicing modulator compounds with in vivo antitumor activity. J Med Chem. 2009; 52:6979-90.

https://doi.org/10.1021/im901215m

PMID: 19877647

61. Takeda J, Seino S, Bell Gl. Human Oct3 gene family: cDNA sequences, alternative splicing, gene organization, chromosomal location, and expression at low levels in adult tissues. Nucleic Acids Res. 1992; 20:4613-20.

https://doi.org/10.1093/nar/20.17.4613 PMID: 1408763

62. Saha SK, Jeong Y, Cho S, Cho SG. Systematic expression alteration analysis of master reprogramming factor OCT4 and its three pseudogenes in human cancer and their prognostic outcomes. Sci Rep. 2018; 8:14806. https://doi.org/10.1038/s41598-018-33094-7 PMID: $\underline{0287838}$

63. Morishima N, Nakanishi K, Nakano A. Activating transcription factor-6 (ATF6) mediates apoptosis 
with reduction of myeloid cell leukemia sequence 1 ( $\mathrm{Mcl}-1)$ protein via induction of $\mathrm{WW}$ domain binding protein 1. J Biol Chem. 2011; 286:3522735.

https://doi.org/10.1074/ibc.M111.233502

PMID:21841196

64. Loh YH, Wu Q, Chew JL, Vega VB, Zhang W, Chen X, Bourque G, George J, Leong B, Liu J, Wong KY, Sung $\mathrm{KW}$, Lee CW, et al. The Oct4 and Nanog transcription network regulates pluripotency in mouse embryonic stem cells. Nat Genet. 2006; 38:431-40.

https://doi.org/10.1038/ng1760

PMID: 16518401

65. Eberle I, Pless B, Braun M, Dingermann T, Marschalek R. Transcriptional properties of human NANOG1 and NANOG2 in acute leukemic cells. Nucleic Acids Res. 2010; 38:5384-95.

https://doi.org/10.1093/nar/gkq307 PMID:20427424

66. Niwa H. How is pluripotency determined and maintained? Development. 2007; 134:635-46.

https://doi.org/10.1242/dev.02787 PMID:17215298

67. Bhavanasi D, Klein PS. Wnt Signaling in Normal and Malignant Stem Cells. Curr Stem Cell Rep. 2016; 2:379-87. https://doi.org/10.1007/s40778-016-0068-y PMID:28503404

68. Dai B, Yang T, Shi X, Ma N, Kang Y, Zhang J, Zhang Y. HMQ-T-F5 (1-(4-(2-aminoquinazolin-7-yl)phenyl)-3(2-bromo-5- (trifluoromethoxy)phenyl) thiourea) suppress proliferation and migration of human cervical HeLa cells via inhibiting Wnt/ $\beta$-catenin signaling pathway. Phytomedicine. 2018; 51:48-57. https://doi.org/10.1016/j.phymed.2018.06.028 PMID: $\underline{30466627}$

69. MacDonald BT, Tamai K, He X. Wnt/beta-catenin signaling: components, mechanisms, and diseases. Dev Cell. 2009; 17:9-26.

https://doi.org/10.1016/i.devcel.2009.06.016 PMID:19619488

70. Yu J, Chen L, Chen Y, Hasan MK, Ghia EM, Zhang L, Wu R, Rassenti LZ, Widhopf GF, Shen Z, Briggs SP, Kipps TJ. Wnt5a induces ROR1 to associate with 14-3$3 \zeta$ for enhanced chemotaxis and proliferation of chronic lymphocytic leukemia cells. Leukemia. 2017; 31:2608-14.

https://doi.org/10.1038/leu.2017.132

PMID:28465528

71. van den Heuvel $M$, Nusse $R$, Johnston $P$, Lawrence PA. Distribution of the wingless gene product in
Drosophila embryos: a protein involved in cell-cell communication. Cell. 1989; 59:739-49.

https://doi.org/10.1016/0092-8674(89)90020-2

PMID: 2582493

72. Behrens J, von Kries JP, Kühl M, Bruhn L, Wedlich D, Grosschedl R, Birchmeier W. Functional interaction of beta-catenin with the transcription factor LEF-1. Nature. 1996; 382:638-42. https://doi.org/10.1038/382638a0 PMID:

73. Hsu TN, Huang CM, Huang CS, Huang MS, Yeh CT, Chao TY, Bamodu OA. Targeting FAT1 Inhibits Carcinogenesis, Induces Oxidative Stress and Enhances Cisplatin Sensitivity through Deregulation of LRP5/WNT2/GSS Signaling Axis in Oral Squamous Cell Carcinoma. Cancers (Basel). 2019; 11:1883.

https://doi.org/10.3390/cancers11121883 PMID:31783581

74. Liang J, Fu Y, Cruciat CM, Jia S, Wang Y, Tong Z, Tao Q, Ingelfinger $D$, Boutros $M$, Meng A, Niehrs C, Wu W. Transmembrane protein 198 promotes LRP6 phosphorylation and Wnt signaling activation. Mol Cell Biol. 2011; 31:2577-90.

https://doi.org/10.1128/MCB.05103-11

PMID:21536646

75. Liu CC, Prior J, Piwnica-Worms D, Bu G. LRP6 overexpression defines a class of breast cancer subtype and is a target for therapy. Proc Natl Acad Sci U S A. 2010; 107:5136-41.

https://doi.org/10.1073/pnas.0911220107 PMID:20194742

76. Zhang J, Li Y, Liu Q, Lu W, Bu G. Wnt signaling activation and mammary gland hyperplasia in MMTVLRP6 transgenic mice: implication for breast cancer tumorigenesis. Oncogene. 2010; 29:539-49. https://doi.org/10.1038/onc.2009.339 PMID:19881541

77. Guha U, Chaerkady R, Marimuthu A, Patterson AS, Kashyap MK, Harsha HC, Sato M, Bader JS, Lash AE, Minna JD, Pandey A, Varmus HE. Comparisons of tyrosine phosphorylated proteins in cells expressing lung cancer-specific alleles of EGFR and KRAS. Proc Natl Acad Sci U S A. 2008; 105:14112-7.

https://doi.org/10.1073/pnas.0806158105 PMID: 18776048

78. Taylor A, Harker JA, Chanthong K, Stevenson PG, Zuniga El, Rudd CE. Glycogen Synthase Kinase 3 Inactivation Drives T-bet-Mediated Downregulation of Co-receptor PD-1 to Enhance CD8(+) Cytolytic T Cell Responses. Immunity. 2016; 44:274-86. https://doi.org/10.1016/j.immuni.2016.01.018 PMID:26885856 
79. Yu D, Kim M, Xiao G, Hwang TH. Review of biological network data and its applications. Genomics Inform. 2013; 11:200-10.

https://doi.org/10.5808/Gl.2013.11.4.200

PMID:24465231

80. Siebring-van Olst E, Blijlevens $M$, de Menezes RX, van der Meulen-Muileman IH, Smit EF, van Beusechem VW. A genome-wide siRNA screen for regulators of tumor suppressor p53 activity in human non-small cell lung cancer cells identifies components of the RNA splicing machinery as targets for anticancer treatment. Mol Oncol. 2017; 11:534-51.

https://doi.org/10.1002/1878-0261.12052

PMID:28296343

81. Steensma DP, Wermke M, Klimek VM, Greenberg PL, Font $\mathrm{P}$, Komrokji RS, Yang J, Brunner AM, Carraway $\mathrm{HE}$, Ades L, Al-Kali A, Alonso-Dominguez JM, AlfonsoPiérola $A$, et al. Phase I First-in-Human Dose Escalation Study of the oral SF3B1 modulator H3B8800 in myeloid neoplasms. Leukemia. 2021; 35:3542-50.

https://doi.org/10.1038/s41375-021-01328-9

PMID:34172893
82. Seiler M, Yoshimi A, Darman R, Chan B, Keaney G, Thomas M, Agrawal AA, Caleb B, Csibi A, Sean E, Fekkes P, Karr C, Klimek V, et al. H3B-8800, an orally available small-molecule splicing modulator, induces lethality in spliceosome-mutant cancers. Nat Med. 2018; 24:497-504.

https://doi.org/10.1038/nm.4493

PMID:29457796

83. Gao Y, Koide K. Chemical perturbation of Mcl-1 premRNA splicing to induce apoptosis in cancer cells. ACS Chem Biol. 2013; 8:895-900. https://doi.org/10.1021/cb300602j

PMID:23485022 
SUPPLEMENTARY MATERIALS

Supplementary Figure

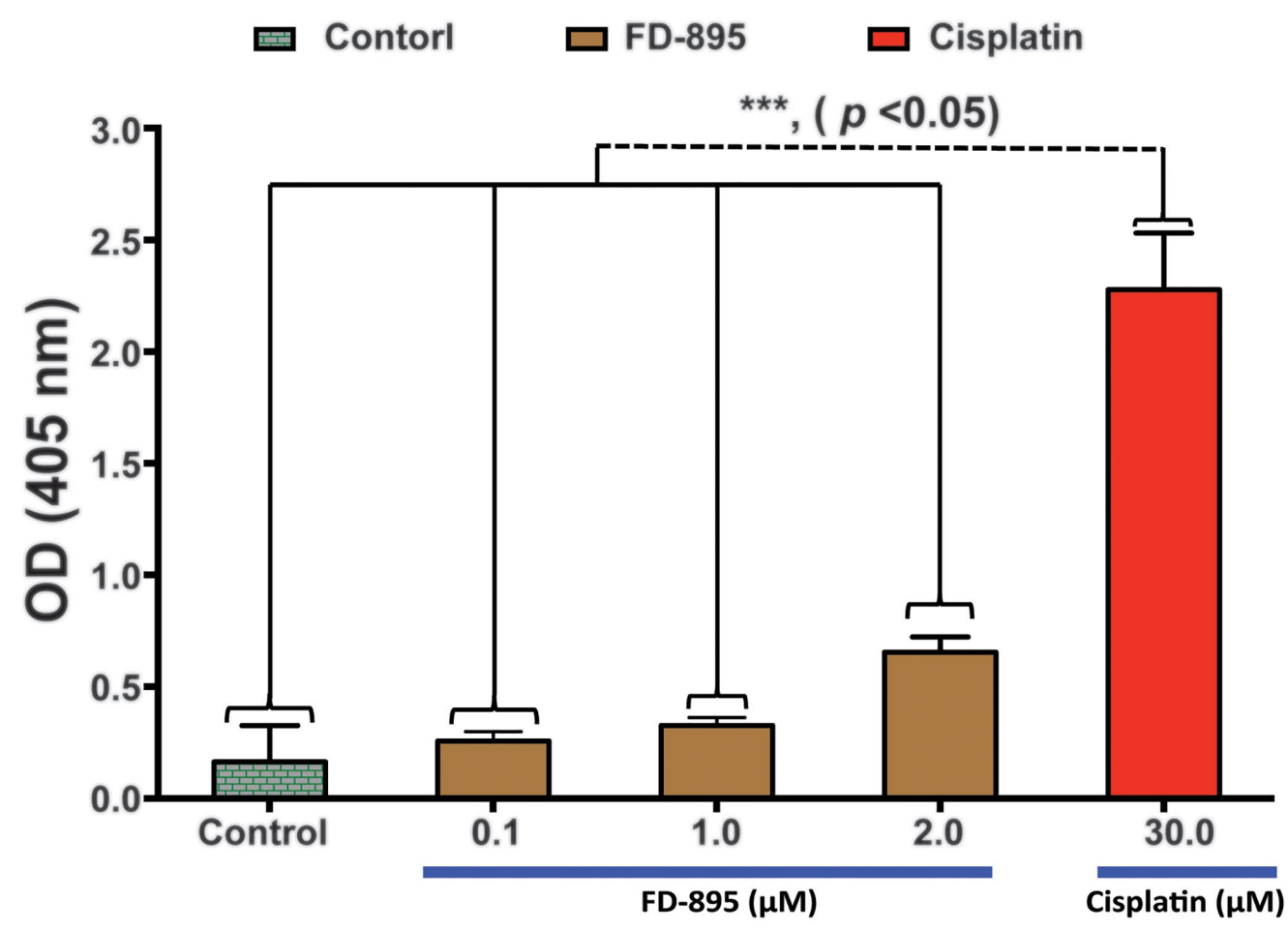

Supplementary Figure 1. In vitro cytotoxicity induced by FD-895 and Cisplatin in HEK-293 cell line. HEK cells were exposed to FD-895 (100 nM to $2 \mu \mathrm{M})$, and cisplatin $(30 \mu \mathrm{M})$ for $48 \mathrm{~h}$. Apoptosis was measured in HEK-293 cells using MTS assay. 